US Army Corps

of Engineers ${ }_{\circledast}$

Engineer Research and

Development Center

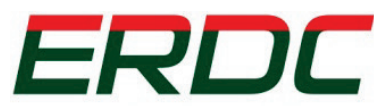

INNOVATIVE SOLUTIONS for a safer, better world

Regional Sediment Management (RSM) Program

Charleston Harbor, SC, Regional Sediment Management Study; Beneficial Use of Dredged Material through Nearshore Placement

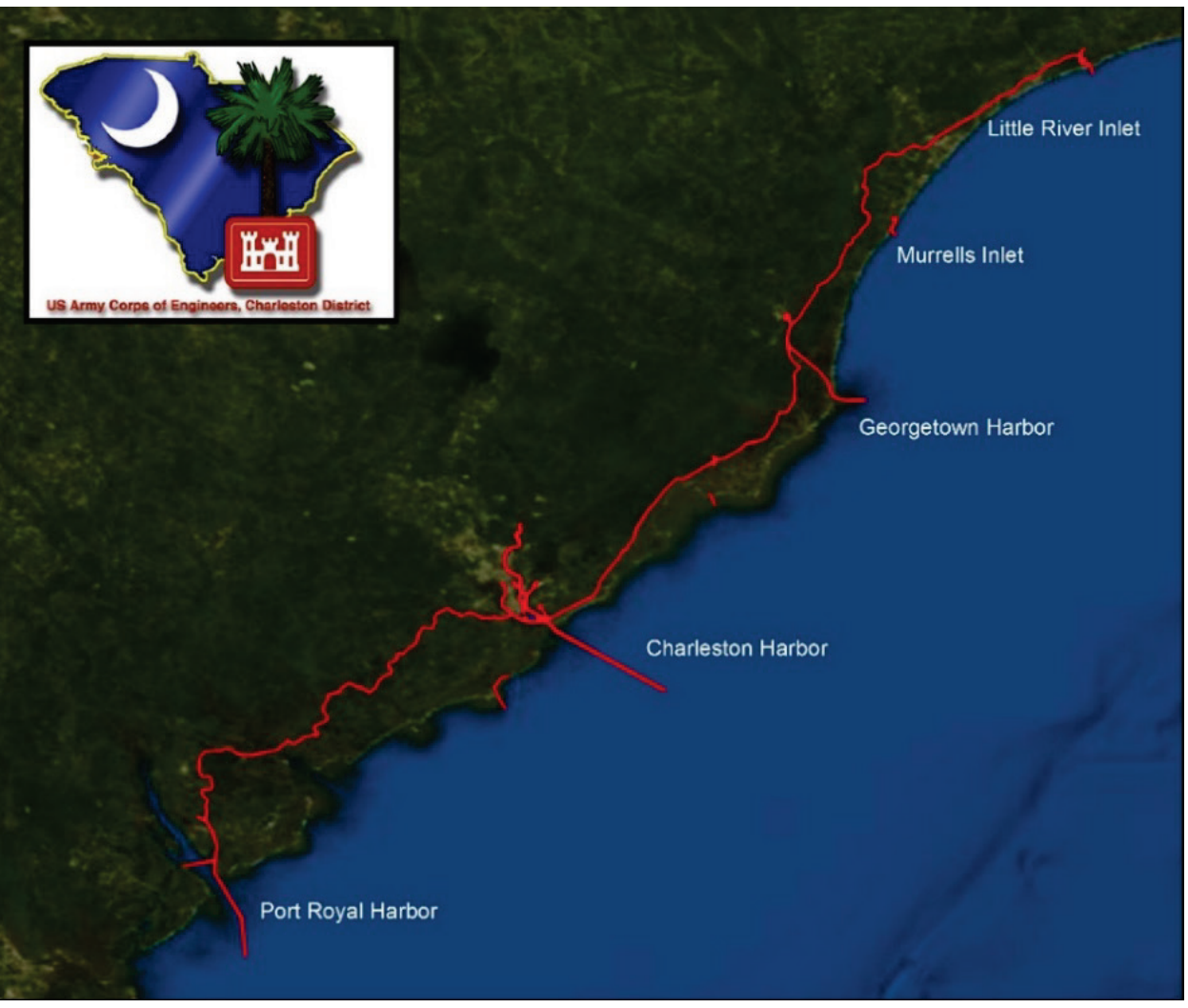


The U.S. Army Engineer Research and Development Center (ERDC) solves the nation's toughest engineering and environmental challenges. ERDC develops innovative solutions in civil and military engineering, geospatial sciences, water resources, and environmental sciences for the Army, the Department of Defense, civilian agencies, and our nation's public good. Find out more at www.erdc.usace.army.mil.

To search for other technical reports published by ERDC, visit the ERDC online library at http://acwc.sdp.sirsi.net/client/default. 


\section{Charleston Harbor, SC, Regional Sediment Management Study; Beneficial Use of Dredged Material through Nearshore Placement}

Layla R. Kashlan

U.S. Army Engineer District, Wilmington

P.O. Box 1890

Wilmington, NC 28402-1890

Sara A. Brown

U.S. Army Engineer District, Charleston

69A Hagood Avenue

Charleston, SC 29403-0919

Linda S. Lillycrop

U.S. Army Engineer Research and Development Center

Coastal and Hydraulics Laboratory

3909 Halls Ferry Road

Vicksburg, MS 39180-6199

Final report

Approved for public release; distribution is unlimited.

Prepared for U.S. Army Corps of Engineers

Washington, DC 20314-1000

Under Project 454632, “Charleston Harbor, SC; Regional Sediment Management Study" 


\section{Abstract}

The 2015 Charleston Harbor, SC, final feasibility study (USACE 2015) presents results of analyses of proposed modifications to the existing navigation system. The improvements would deepen the Entrance Channel from -47 feet (ft) mean lower low water (mllw) to $-54 \mathrm{ft}$ mllw.

The dredged material is estimated to be $80 \%$ sand and does not meet U.S. Army Corps of Engineers guidelines for beach placement. Instead of disposing in the Ocean Dredged Material Disposal Site, nearshore placement is considered as a beneficial use. The U.S. Army Engineer Research and Development Center CMS-Flow and CMS-Wave numerical models were utilized to estimate benefits from nearshore placement of 400,000 cubic meters $(523,000$ cubic yards) of new work in three areas south of the Harbor south jetty.

The least sediment erosion occurred where the material was placed in Area 1, the location nearest the shoreface. This resulted in maximum deposition along the Morris Island southern shoreline and least deposition inside the Entrance Channel and in the ebb-tide delta of Lighthouse Inlet. As more details of the new work dredge material become available, this analysis will be re-evaluated with longer simulations to better understand morphology changes along Morris Island and the northern portion of Folly Island.

DISCLAIMER: The contents of this report are not to be used for advertising, publication, or promotional purposes. Citation of trade names does not constitute an official endorsement or approval of the use of such commercial products. All product names and trademarks cited are the property of their respective owners. The findings of this report are not to be construed as an official Department of the Army position unless so designated by other authorized documents. 


\section{Contents}

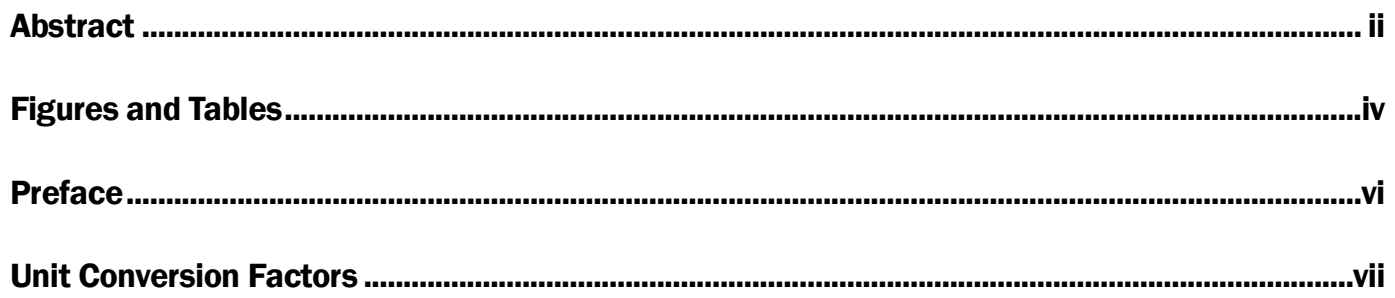

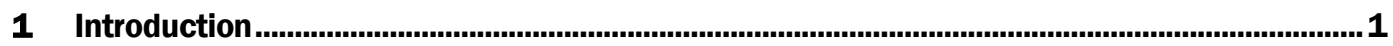

Regional Sediment Management (RSM) Program ......................................................... 1

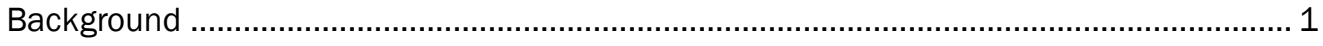

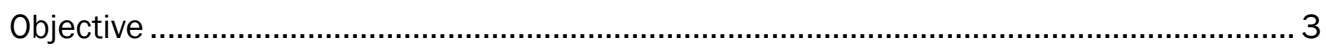

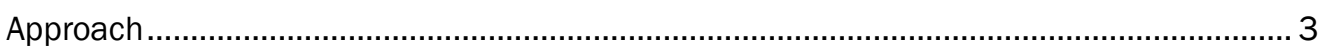

2 Measured Current and Wave Data ...................................................................................... 5

3 Identification of Potential Nearshore Placement Areas for Dredged Material....................10

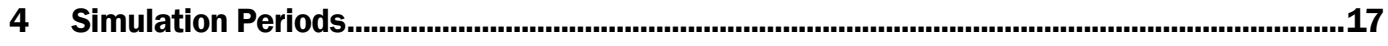

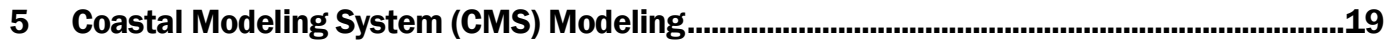

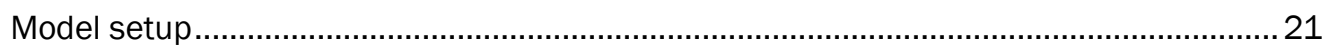

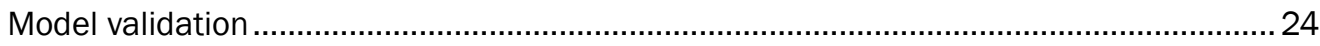

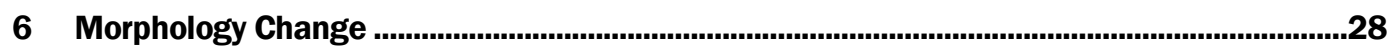

7 Particle Tracking Model (PTM)

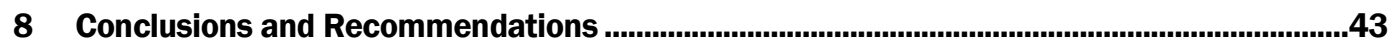

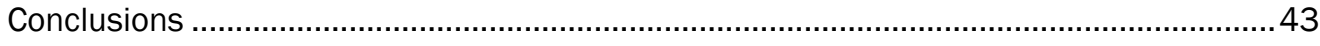

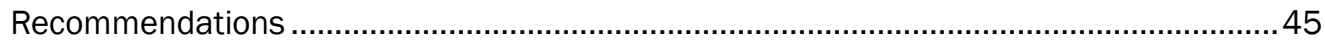

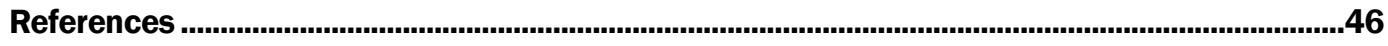

\section{Report Documentation Page}




\section{Figures and Tables}

\section{Figures}

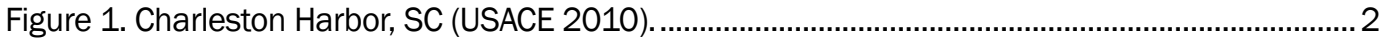

Figure 2. ADCP locations (EPA 2014) ........................................................................................ 6

Figure 3. Wave-height rose at the Offshore ADCP (EPA 2014) ....................................................... 8

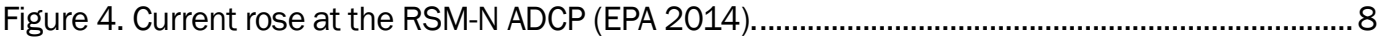

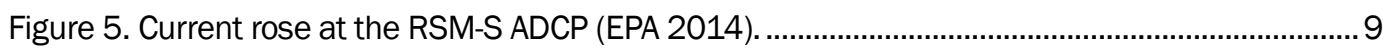

Figure 6. Current rose at the Offshore ADCP (EPA 2014) .................................................................

Figure 7. Bathymetric change. (Figure 7a, left [1921-1964]; Figure 7b, right [1964-present])...............11

Figure 8. Bathymetric contours south of Charleston Harbor Entrance Channel, 1964 (left)

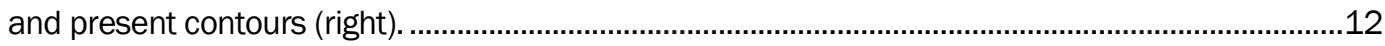

Figure 9. Breaker index during storm weather (left) and calm weather (right).................................13

Figure 10. Nearshore berm stability graph illustrating the difference between active and stable berms in deep or shallow water. (Beck et al. [2012], as modified from Hands and Allison [1991].) ................................................................................................................................

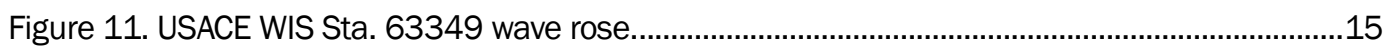

Figure 12. Potential areas for nearshore placement. ……..........................................................16

Figure 13. Wave height at the Offshore ADCP during the selected active winter period. ...................17

Figure 14. Wave height at the Offshore ADCP during the selected calm summer period.................17

Figure 15. Location map of coastal wind stations.........................................................................18

Figure 16. The USACE CMS framework and its components (Demirbilek and Rosati 2011)...........19

Figure 17. CMS-Flow (blue) and CMS-Wave (red) model domains, Charleston Harbor Entrance Channel...................................................................................................................

Figure 18. Increased grid resolution within the three potential placement areas.............................22

Figure 19. Location map of the USGS flow gauges on the Ashley, Cooper, and Wando Rivers. ..........23

Figure 20. Comparison of measured and modeled wave height at RSM-S ADCP during active winter simulation period.

Figure 21. Comparison of measured, modeled, and filtered principal current at RSM-S ADCP during active winter simulation period. Positive currents are during the flooding tide; negative currents are during the ebbing tide.

Figure 22. Comparison of measured and modeled wave height at RSM-S ADCP during calm summer simulation period.

Figure 23. Comparison of measured and modeled principal current at RSM-S ADCP during calm summer simulation period. Positive currents are during the flooding tide; negative currents are during the ebbing tide.

Figure 24. Morphology change at end of active winter period for existing condition. ........................28

Figure 25. Morphology change at end of active winter period for placement at Area 1...................29

Figure 26. Morphology change at end of active winter period for placement at Area 2...................29

Figure 27. Morphology change at end of active winter period for placement at Area 3.....................30

Figure 28. Morphology change at end of calm summer period for existing condition.......................32

Figure 29. Morphology change at end of calm summer period for placement at Area 1................32 
Figure 30. Morphology change at end of calm summer period for placement at Area 2 33

Figure 31. Morphology change at end of calm summer period for placement at Area 3

Figure 32. Morphology change difference between existing and with placement at Area 1 at end of active winter period. (There is no change in the areas not shown on the figure.).

Figure 33. Morphology change difference between existing and with placement at Area 2 at end of active winter period. Since the dynamite hole region is very active, morphology change is expected to be observed during the short time of the simulation. (There is no change in the regions not shown on the figure.)

Figure 34. Morphology change difference between existing and with placement at Area 3 at end of active winter period. (There is no change in the areas not shown on the figure.). 36

Figure 35. Morphology change difference between existing and with placement at Area 1 at end of calm summer period. (There is no change in the regions not shown on the figure.)

Figure 36. Morphology change difference between existing and with placement at Area 2 at end of calm summer period. (There is no change in the regions not shown on the figure.). 38

Figure 37. Morphology change difference between existing and with placement at Area 3 at end of calm summer period. (There is no change in the regions not shown on the figure.).....

Figure 38. Silt particle distribution at end of 7-day simulation at Area 1. Red particles indicate deposited sediments. Blue particles indicate sediment in suspension.

\section{Tables}

Table 1. ADCP deployment periods (EPA 2014) ........................................................................... 7

Table 2. Grain size distribution of dredged material. .........................................................................10

Table 3. Potential placement areas footprint. ...................................................................................24

Table 4. Net volume change over active winter period, and calm summer period, with the $400,000 \mathrm{~m}^{3}\left(523,000 \mathrm{yd}^{3}\right)$ of dredged material placement at each proposed area. 


\section{Preface}

This study was conducted for Headquarters, U.S. Army Corps of Engineers (HQUSACE), Washington, DC, under the USACE Regional Sediment Management (RSM) Program; Project 454632, "Charleston Harbor, SC, Regional Sediment Management Study” Project. The HQUSACE RSM Program Manager was Ms. Linda S. Lillycrop, U.S. Army Engineer Research and Development Center (ERDC), Coastal and Hydraulics Laboratory (CHL), Navigation Division (HN), Coastal Engineering Branch (HN-C). Mr. Jeffrey A. McKee was the HQUSACE Navigation Business Line Manager overseeing the RSM Program.

The work was performed by the U.S. Army Engineer District, Charleston (SAC); the U.S. Army Engineer District, Wilmington (SAW); and the ERDC, CHL, HN, HN-C. At the time of publication, Ms. Tanya M. Beck was Chief, HN-C; Dr. Jackie S. Pettway was Chief, HN; and Mr. W. Jeff Lillycrop (CHL) was the ERDC Technical Director for Civil Works and the Navigation Research, Development, and Technology Transfer (RD\&T) portfolio. The Deputy Director of CHL was Mr. Jeffrey R. Eckstein, and the Director of CHL was Mr. José E. Sánchez.

The Commander of ERDC was COL Bryan S. Green, and the Director was Dr. David W. Pittman. 


\section{Unit Conversion Factors}

\begin{tabular}{|l|l|l|}
\hline Multiply & By & To Obtain \\
\hline cubic yards & 0.764555 & cubic meters \\
\hline feet & 0.3048 & meters \\
\hline nautical miles & 1.852 & kilometers \\
\hline square miles & 2.58999 & square kilometers \\
\hline
\end{tabular}




\section{Introduction}

\section{Regional Sediment Management (RSM) Program}

Regional Sediment Management (RSM) is a systems-based approach for managing sediments that is implemented collaboratively with other federal, state, and local agencies. The objective of the U.S. Army Corps of Engineers (USACE) RSM Program is to improve the management of sediments across multiple projects, manage sediments as a regional-scale resource, and implement adaptive management strategies that support sustainable navigation and dredging, flood and storm damage reduction, and environmental practices that increase operational efficiencies, the value of sediments, and social and environmental/ecosystem benefits while reducing lifecycle costs. RSM is also a means of involving stakeholders to leverage resources, share technology and data, identify needs and opportunities, and develop solutions to improve the utilization and management of sediments. Implementation of RSM provides a better understanding of the regional sediment transport processes through integration of regional data and application of tools that improve knowledge of the regional processes, provides a means to understand and share demands for sediment, and results in identifying and implementing adaptive management strategies to optimize use of sediments and streamline projects. The adaptive management strategies are developed and implemented through application of the best available science and engineering practices and use of policies and authorities that facilitate regional approaches. Benefits of this approach are improved partnerships with stakeholders, improved sediment utilization and project management on a regional scale, improved environmental stewardship, and reduced overall lifecycle costs (Lillycrop et al. 2011).

\section{Background}

Charleston Harbor is a natural tidal estuary located along the coast of Charleston, SC. The harbor covers a region of approximately 14 square miles and is formed by the confluence of the Ashley, Cooper, and Wando Rivers. The inlet is situated within a chain of barrier islands with Sullivan's Island and Isle of Palms to the north and Morris and Folly Islands to the south (Figure 1). The Charleston Harbor Entrance Channel is flanked by a dual weir-jetty system. The rubble-mound jetties, located 885 meters (m) 
$(2,900$ feet [ft]) apart, were constructed between 1878 and 1886, with a shoreward submerged weir section and a seaward raised section (Sargent 1988).

Figure 1. Charleston Harbor, SC (USACE 2010).

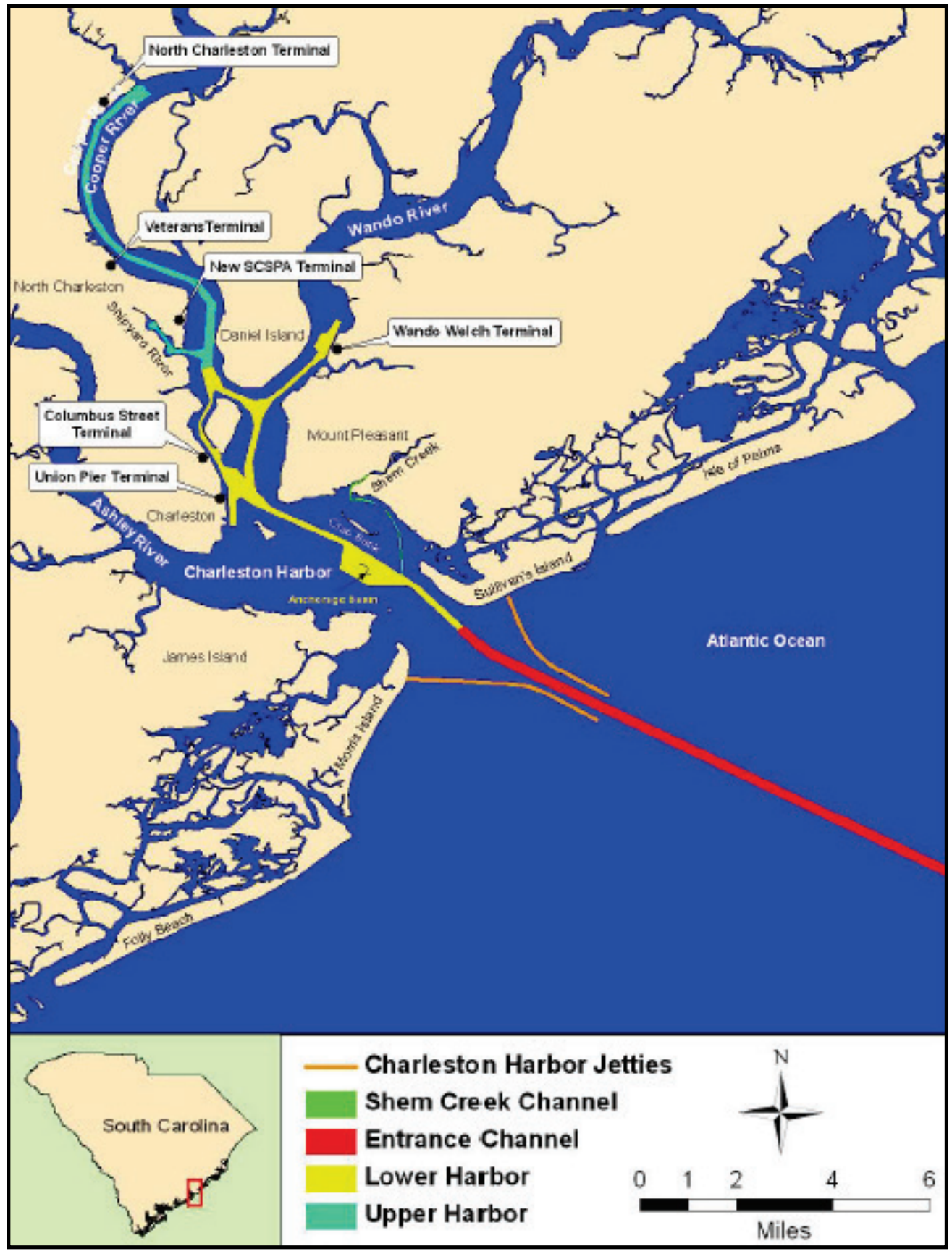

Dredging records from 1994 to 2008 indicate the average annual channel maintenance dredging quantities were approximately 1.45 million cubic meters $\left(\mathrm{m}^{3}\right)$ (1.9 million cubic yards [yd3]) from the Federal channels with 
an additional 306,000 $\mathrm{m}^{3}(400,000 \mathrm{yd} 3)$ from maintenance dredging of a non-federal berth. The Entrance Channel is dredged using a hopper dredge, and the material is transported and placed into the Charleston Harbor Ocean Dredged Material Disposal Site (ODMDS) (USACE 2009).

USACE guidance (Coastal Engineering Manual, USACE 2008) suggests that material for direct beach placement should be composed of greater than $88 \%$ sand. Dredged material that is not beach quality but has a high percentage of sand is an attractive source for beneficial use (Gailani et al. 2007). Beneficial use of dredged material is defined as utilizing dredged sediments as resource materials in productive ways that provide environmental, economic, or social benefit (ANAMAR 2013). At the time of this study, available sediment data from the Charleston Entrance Channel showed that material to be dredged under the deepening project is composed of approximately $80 \%$ sand and thus does not meet general guidelines for direct beach placement. Rather than transporting the material to the offshore ODMDS and consequently permanently removing the sediments from the littoral system, nearshore placement is being considered to beneficially use the dredged material in the vicinity of Charleston Harbor.

\section{Objective}

The objective of this study is to assess the sediment transport associated with approximately $400,000 \mathrm{~m}^{3}(523,000 \mathrm{yd} 3)$ of new work material dredged from the Charleston Harbor Entrance Channel and placed into the nearshore regions south of the Charleston Harbor south jetty (Figure 1). Nearshore placement of the dredged material, composed of approximately 80\% sand, will keep the sediment in the littoral transport zone and has the potential to reduce shoreline erosion along Folly Island, which is located downdrift of Charleston Harbor.

\section{Approach}

This study included numerical modeling of coastal hydrodynamics, wave transformation, and sedimentation in the coastal region of Charleston Harbor. The numerical models were applied to evaluate hydrodynamic and morphology change associated with nearshore placement as well as to identify any potential adverse impacts associated with placement. 
The Coastal Modeling System (CMS) is an integrated suite of numerical models for simulating water-surface elevation, current, waves, sediment transport, and morphology change in coastal and inlet applications (Demirbilek and Rosati 2011; Sanchez et al. 2011a). The CMS-Wave model (Lin et al. 2008, 2011) estimates wave transformation, and the CMS-Flow model (Buttolph et al. 2006; Sanchez et al. 2011b) estimates water-surface elevations, currents, and sediment transport. Sediment transport and morphology change can be computed as a user-specified option. The models calculate time-dependent water elevation, current speed and direction, erosion and accretion, and sediment transport flux. The CMS-Wave and CMS-Flow models can be coupled with the Particle Tracking Model (PTM) (Demirbilek et al. 2008) to estimate sediment pathways.

CMS-Flow and CMS-Wave numerical models and field data (nearshore bathymetry, currents, waves, astronomical tide, and river flow) collected for a previous Charleston Harbor numerical model study (Kashlan 2013) were used in this study. Three proposed locations for nearshore placement were identified based on review of relevant historical data, distance from the navigation channel, and berm stability criteria. Placement Area 1 is located in the Morris Island surf zone, at approximately $3.5 \mathrm{~m} \mathrm{(11.5 \textrm {ft } )}$ water depth. Placement Areas 2 and 3 are farther offshore at $4.5 \mathrm{~m}$ $(14.8 \mathrm{ft})$ and $5.5 \mathrm{~m}(18.0 \mathrm{ft})$ water depth, respectively. All three areas are within the depth of closure (DOC) (9.5 m [31 ft]). Sediment transport and morphology changes at the three proposed nearshore placement areas, and the study region beaches and shoals, were investigated during representative active winter and calm summer conditions. 


\section{Measured Current and Wave Data}

Current and wave data were collected in a previous study to designate a new ODMDS for Charleston Harbor. The new ODMDS was designated by the U.S. Environmental Protection Agency (EPA) in 1987 for the disposal of dredged material from the greater Charleston, SC, region. Since 1987, approximately 37.5 million $\mathrm{m}^{3}$ (49 million $\mathrm{yd}$ ) ) of dredged material has been disposed into the ODMDS. Through the USACE Charleston District (SAC) Charleston Harbor Deepening Study, SAC determined that deepening the harbor would generate a volume of dredged material that exceeds the existing capacity of the Charleston ODMDS. Consequently, SAC determined that a modification of the existing ODMDS will be needed to accommodate dredged material from the deepening project.

SAC requested that EPA Region 4 conduct a 1-year study of the circulation (currents) and waves in the vicinity of a new Charleston Harbor ODMDS in support of site designation (McArthur 2012). This task involved multiple deployment and retrievals of acoustic Doppler current profilers (ADCP) to measure currents and waves within the proposed modified ODMDS study region and around the Charleston Harbor Entrance Channel. EPA (2014) stated that the study region (Figure 2) consisted of (a) the Charleston Harbor ODMDS (an area approximately 28 kilometers $(\mathrm{km})$ (15.1 nautical miles [nm]) offshore of the entrance to Charleston Harbor); (b) the region north and south of the ends of the Charleston Harbor jetty; and (c) a location approximately $50 \mathrm{~km}(27 \mathrm{~nm})$ offshore the entrance to Charleston Harbor in deep water (approximately $27 \mathrm{~m}[90 \mathrm{ft}]$ ). The instruments required four deployments each of 3 to 5 months beginning on 7 November 2012. The deployment periods are listed in Table 1. These data were used for this analysis as well.

A wave-height rose for the entire deployment period at the Offshore station is shown in Figure 3. Waves are predominately out of the eastsoutheast (ESE) and seldom exceed $2.5 \mathrm{~m}(8 \mathrm{ft})$ in height at the Offshore station. Current roses for depth average currents at RSM-N and RSM-S ADCPs are shown in Figures 4 and 5, respectively. The RSM-N station has a predominately west-southwest flow while the RSM-S station has a northnorthwest and ESE flow. The Offshore station does not have a dominant flow direction although the strongest currents flow northeast and southwest as shown in Figure 6, which depicts the current rose at the Offshore ADCP (EPA 2014). 
Figure 2. ADCP locations (EPA 2014).

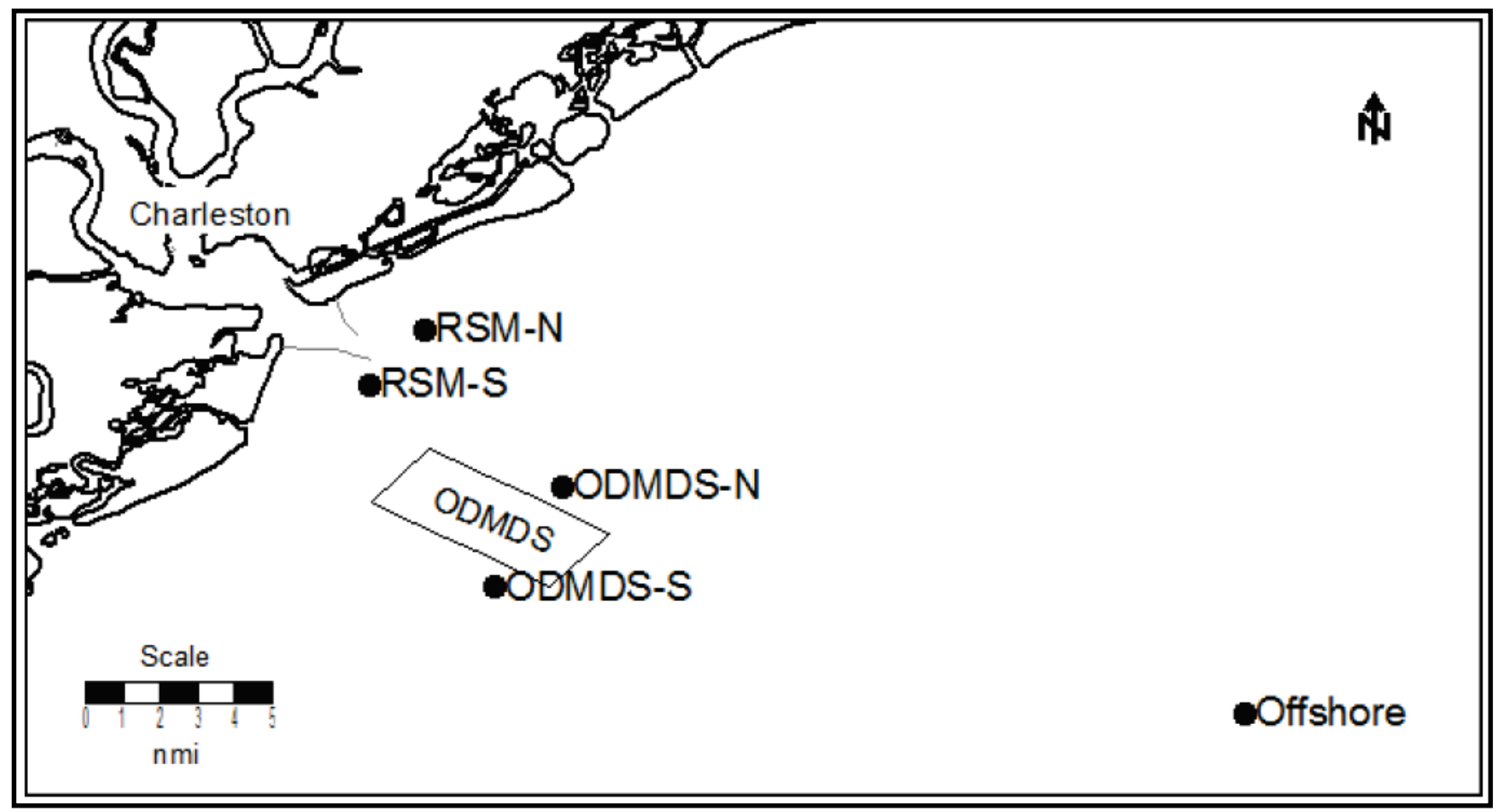


Table 1. ADCP deployment periods (EPA 2014).

\begin{tabular}{|c|c|c|}
\hline First Ensemble Date - Time (UTC) & Last Ensemble Date - Time (UTC) & $\begin{array}{l}\text { Duration } \\
\text { (days) }\end{array}$ \\
\hline \multicolumn{3}{|c|}{ RSM-N } \\
\hline $11 / 08 / 12-21: 00$ & $11 / 11 / 12-10: 00$ & $3^{1}$ \\
\hline $\begin{array}{l}\text { Currents: 03/20/13 - 19:00 } \\
\text { Waves: 03/20/13 - 19:00 }\end{array}$ & $\begin{array}{l}05 / 04 / 13-03: 00 \\
06 / 08 / 13-13: 00\end{array}$ & $\begin{array}{l}44^{2} \\
80\end{array}$ \\
\hline Total & Currents: 47 & Waves: 83 \\
\hline \multicolumn{3}{|c|}{ RSM-S } \\
\hline $11 / 08 / 12-15: 00$ & 02/06/13 - 16:00 & 90 \\
\hline 02/06/13 - 18:00 & 06/05/13 - 16:00 & 119 \\
\hline Total & & 209 \\
\hline \multicolumn{3}{|c|}{ ODMDS-N } \\
\hline $11 / 08 / 12-17: 30$ & 02/06/13 - 20:30 & 90 \\
\hline 02/06/13 - 21:15 & $06 / 05 / 13-21: 30$ & 119 \\
\hline 06/05/13 - 21:30 & 09/04/13 - 21:00 & 91 \\
\hline $09 / 04 / 13-17: 10$ & 02/20/14 - 19:30 & 169 \\
\hline Total & & 469 \\
\hline \multicolumn{3}{|c|}{ ODMDS-S } \\
\hline $11 / 07 / 12-17: 30$ & 02/05/13 - 21:00 & 90 \\
\hline $02 / 05 / 13-21: 50$ & 06/06/13 - 15:50 & 121 \\
\hline 06/06/13 - 16:00 & 09/04/13 - 16:00 & 90 \\
\hline 09/04/13 - 17:10 & 02/19/14 - 10:10 & 168 \\
\hline Total & & 469 \\
\hline \multicolumn{3}{|c|}{ Offshore } \\
\hline 11/09/12 - 19:20 & $12 / 31 / 12-21: 40$ & $52^{3}$ \\
\hline 03/19/13 - 21:30 & 06/04/13 - 19:30 & 77 \\
\hline $\begin{array}{l}\text { Currents: 06/04/13 - 19:40 } \\
\text { Directional Waves: 06/05/13 - 01:00 } \\
\text { Non-Directional Waves: 07/15/13 - 10:00 }\end{array}$ & $\begin{array}{l}\text { 08/11/13 - 09:004 } \\
07 / 15 / 13-10: 00^{5} \\
08 / 11 / 13-16: 00\end{array}$ & $\begin{array}{l}67 \\
40 \\
27\end{array}$ \\
\hline
\end{tabular}

1Bad central processing unit (CPU) board caused instrument failure. 2Instrument burial prohibited collection of current data after 05/04/13.

3 Power failure resulted in premature instrument shutdown on 12/13/12.

4Power failure resulted in premature instrument shutdown on 08/11/13.

5Pressure sensor failure on $07 / 15 / 12$ resulted in the inability to determine directional wave parameters. 
Figure 3. Wave-height rose at the Offshore ADCP (EPA 2014).

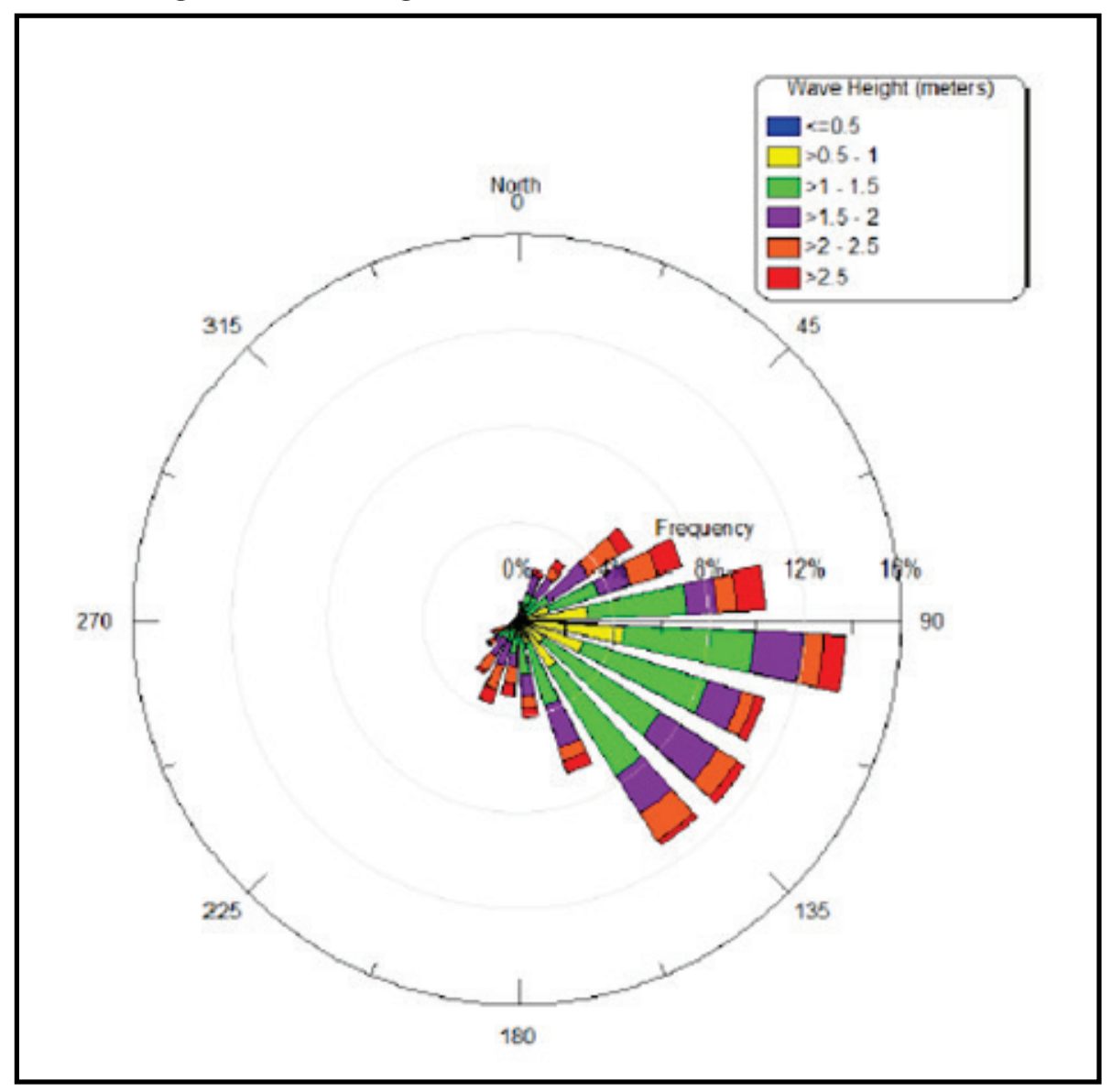

Figure 4. Current rose at the RSM-N ADCP (EPA 2014).

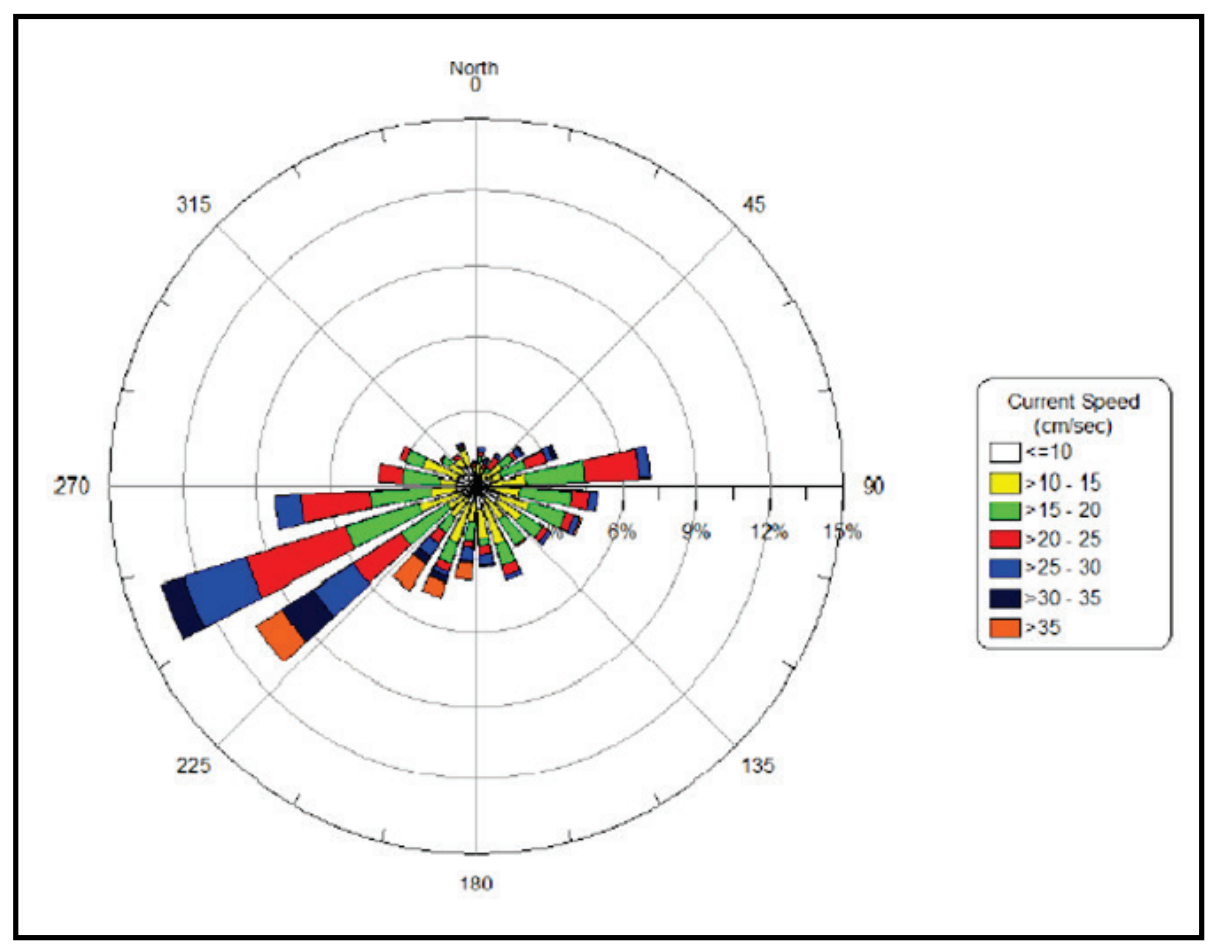


Figure 5. Current rose at the RSM-S ADCP (EPA 2014).

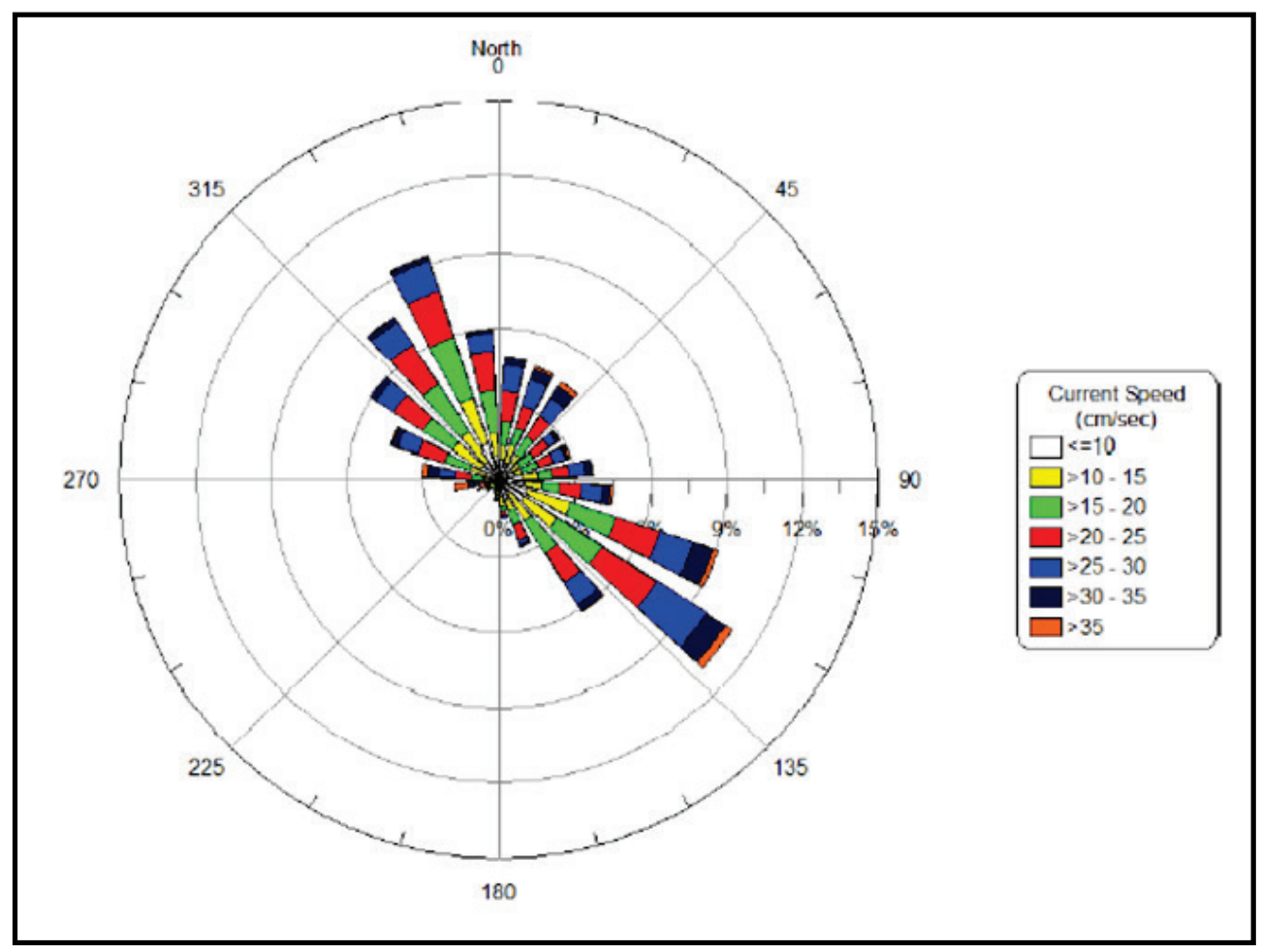

Figure 6. Current rose at the Offshore ADCP (EPA 2014).

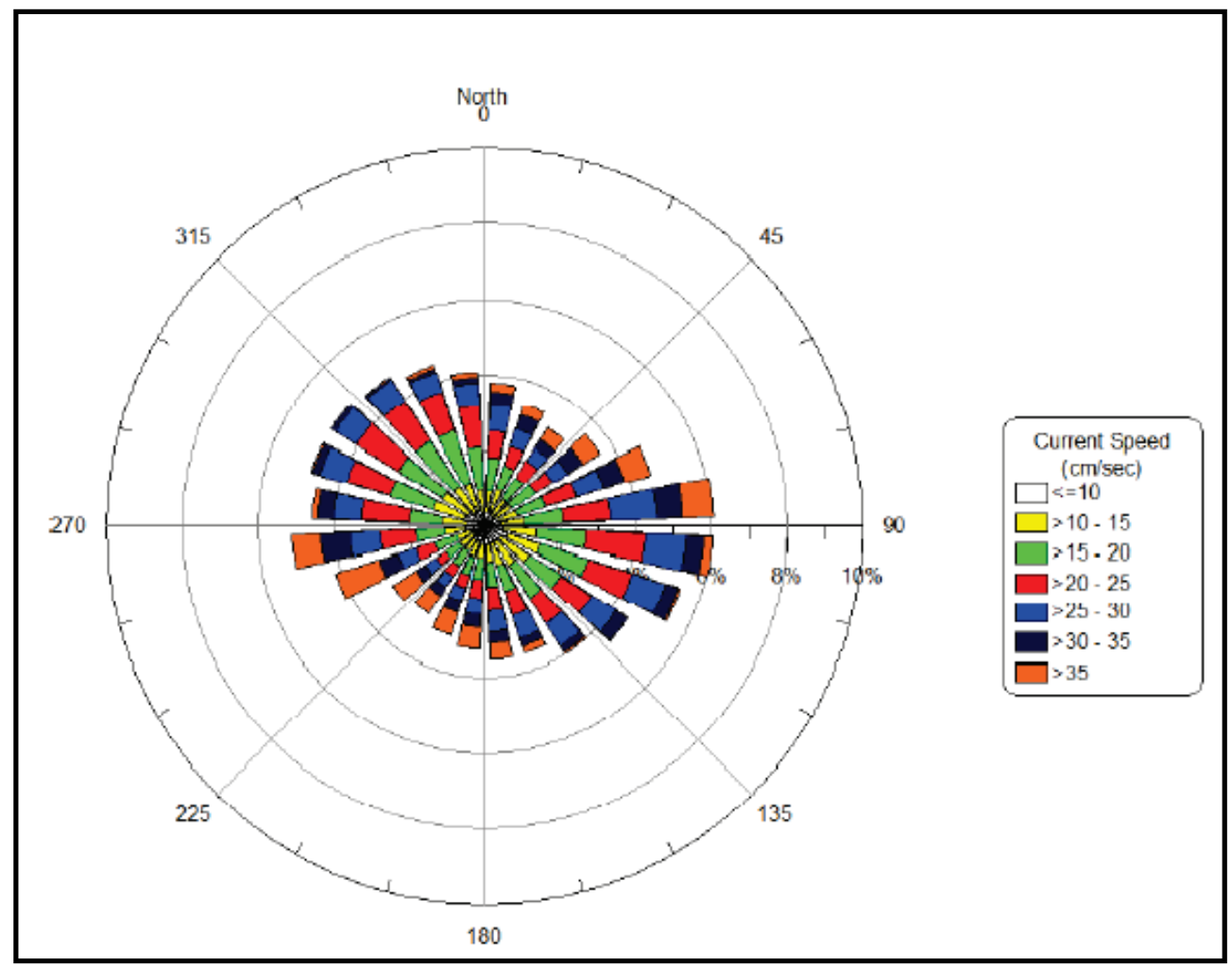




\section{Identification of Potential Nearshore Placement Areas for Dredged Material}

Sediment samples from representative locations throughout the Charleston Harbor region were collected and evaluated (ANAMAR 2013). There was only one sample of the dredged material obtained from the Entrance Channel, and it was composed of $76.3 \%$ sand with a small percentage of gravel, silt, and clay (Table 2). The dredged material does not meet guidelines for direct beach placement. Therefore, nearshore placement could be an alternative to direct beach placement, and locations of potential placement need to be identified. Gailani et al. (2007) stated that dredged material composed of approximately 20\% silt and clay does not meet USACE guidelines for direct beach placement. Therefore, nearshore placement is considered a promising alternative to direct beach placement for which winnowing by wave action will naturally separate sand and silt fractions. It is likely the coarser sand fraction will remain in the nearshore while fine-grained sediment will be suspended by high wave energy in the nearshore and transported offshore due to sand grain entrainment in the orbital wave velocities. The settling velocity of finer grains is greater than for coarser grains; thus, the finer grains get trapped in the orbital motion of the waves for longer periods of time and move offshore.

Table 2. Grain size distribution of dredged material.

\begin{tabular}{|l|l|}
\hline Sediment & Grain Fractions (\%) \\
\hline Gravel & 4.0 \\
\hline Sand & 76.3 \\
\hline Silt & 9.7 \\
\hline Clay & 10.0 \\
\hline
\end{tabular}

Morris Island is located immediately south of the Charleston Harbor Entrance Channel. According to Fitzgerald et al. (1979), the Morris Island shoreline has retreated continuously throughout historic time along all but the island's northeastern tip where it presently stands northeast of its 1860 s position (Stapor and May 1987). Sediment eroded from the southern three-fourths of Morris Island at approximately $160,000 \mathrm{~m} 3 /$ year (210,000 $y d 3 /$ year). Throughout the region south of the jetty channel, the 
ebb tidal delta has been reworked, and the eroded sediment moved primarily onshore and towards the northeast tip of Morris Island.

Figure 7a (left) shows the bathymetry difference between 1921 and 1964 surveys (Stapor and May 1987). The Surface-water Modeling System 11.0 (SMS 11.0) was used to estimate the bathymetry difference between the latest available surveys (present) and a National Oceanic and Atmospheric Administration survey of 1964 (Figure 7b, right). This figure shows that the depositional region south of the weir, in front of the upper portion of Morris Island, decreased while the depositional region south of the raised seaward jetty increased. Also, this figure shows that the shoal in front of the middle portion of Morris Island increased.

Figure 7. Bathymetric change. (Figure 7a, left [1921-1964]; Figure 7b, right [1964-present]).

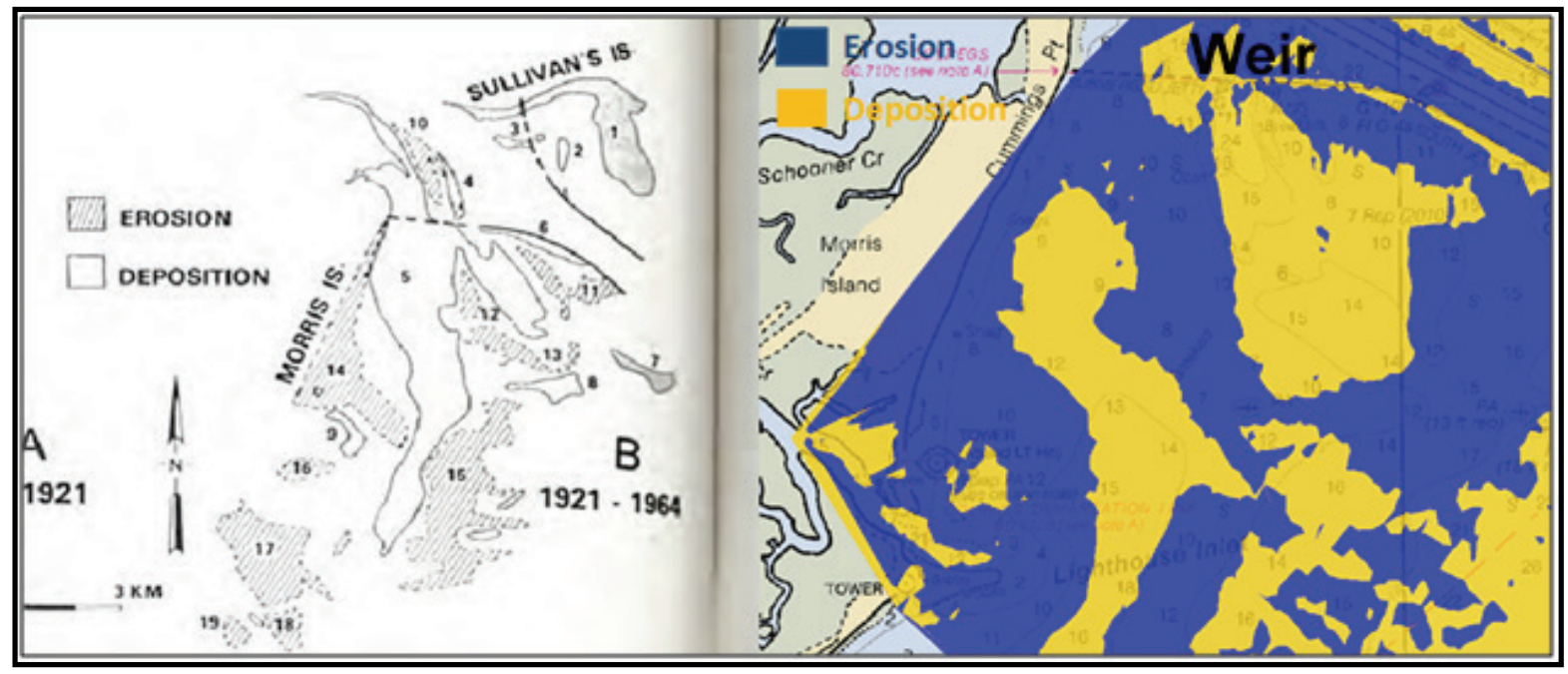

Hansen and Knowles (1988) stated that major changes in the geomorphic configuration of the ebb-tidal delta occurred between 1900 and 1921. Most dramatic was the re-diversion and infilling of the remnant main-ebb channel. The remnant main-ebb channel just south of the south jetty scoured a major breach through the seaward shoals during this time period. Source of the infilling was probably from landward migration of swash platform regions, and material that eroded from Morris Island. Between 1900 and 1921, the large swash platform region south of the inlet fragmented into smaller regions. By 1960, most of these regions had been consolidated again into a large shoal seaward of Morris Island, delineated

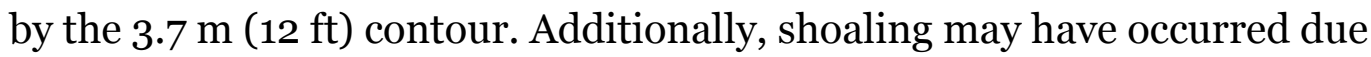
to sediment transport offshore of the rapidly eroding southern end of 
Morris Island. During 1985, the remnant main-ebb channel diversion had shoaled slightly.

Figure 8 shows the $3.5 \mathrm{~m}(11.5 \mathrm{ft}), 4.5 \mathrm{~m}(14.8 \mathrm{ft})$, and $5.5 \mathrm{~m}(18.0 \mathrm{ft})$ contours in 1964 (left) and in the present surveys (right). It appears that the consolidation and migration of the fragmentation swash shoals in front of Morris Island are continuing. Also, the shoal adjacent to the south jetty is growing and extending southward and landward, and the remnant main-ebb channel is infilling.

Figure 8. Bathymetric contours south of Charleston Harbor Entrance Channel, 1964 (left) and present contours (right).

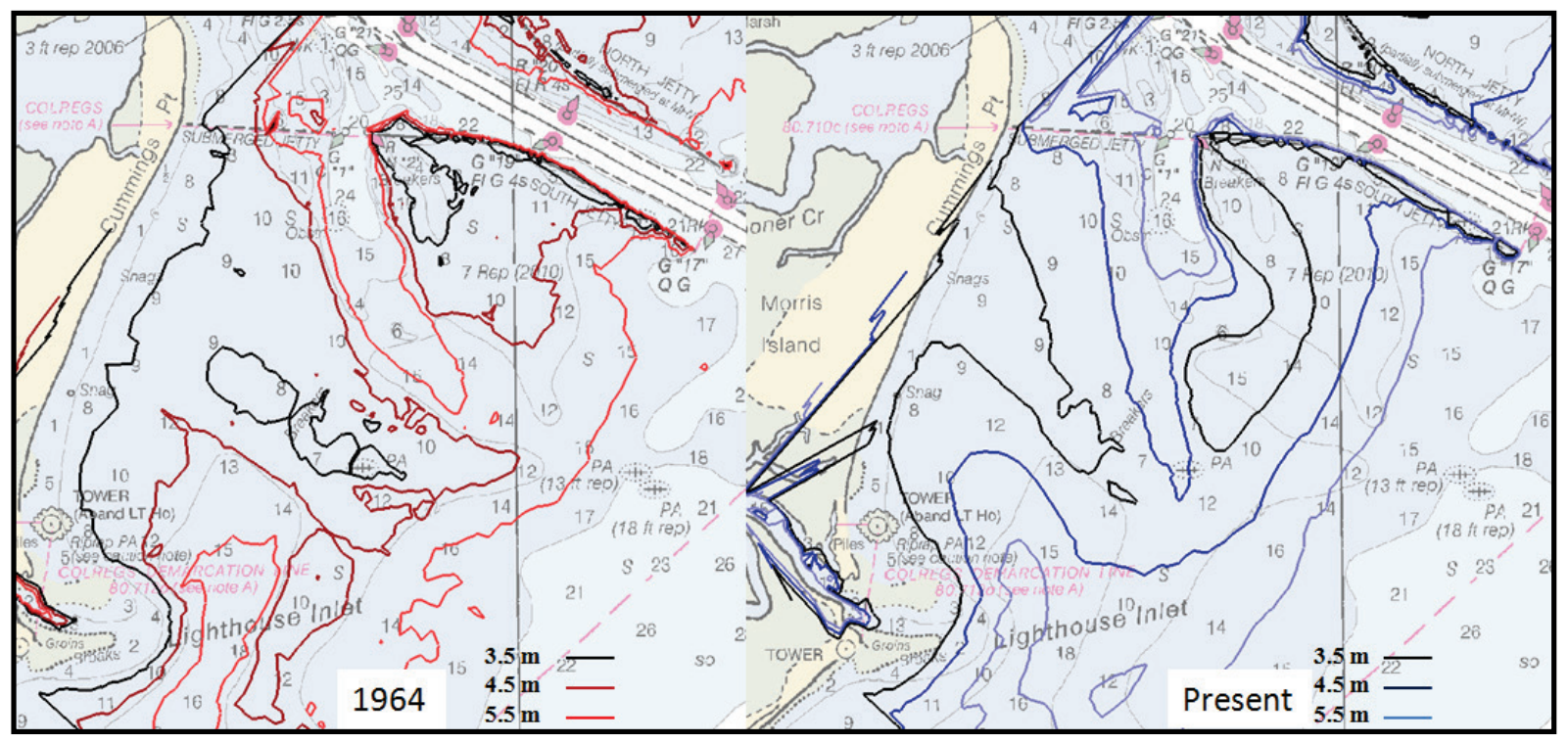

Smith and Gailani (2005) suggested that nearshore mound locations, material, and configurations be chosen judiciously to assure that the mound does not negatively impact the surrounding environment and that the material remains in the littoral system and potentially nourishes the beach. Although nearshore mounds are generally placed outside the surf zone, these same locations are within or around the surf zone during storms. Storm events are the predominant transport mechanism for nearshore mounds. Material placement near the breaker region permits wave asymmetry to induce a net onshore direction of mound migration and dispersion. The impact of wave asymmetry is reduced significantly outside this zone. Placement in the relatively narrow, calm-weather surf zone is often not an option. However, the surf zone becomes much wider during storms. Therefore, defining the storm surf zone for possible 
placement locations is important, and can contribute significantly to the success of using nearshore placement to feed the littoral system.

The USACE CMS-Wave model (Kashlan 2013) was applied for both storm and calm wave conditions. In general, wave breaking occurs in the grid row closer to the shoreline where the breaker index changes from 0 to 1. Figure 9 shows that the surf zone (the nearshore region inside the wave breaking line) during extreme weather conditions extends farther seaward than during relatively calm conditions.

Figure 9. Breaker index during storm weather (left) and calm weather (right).

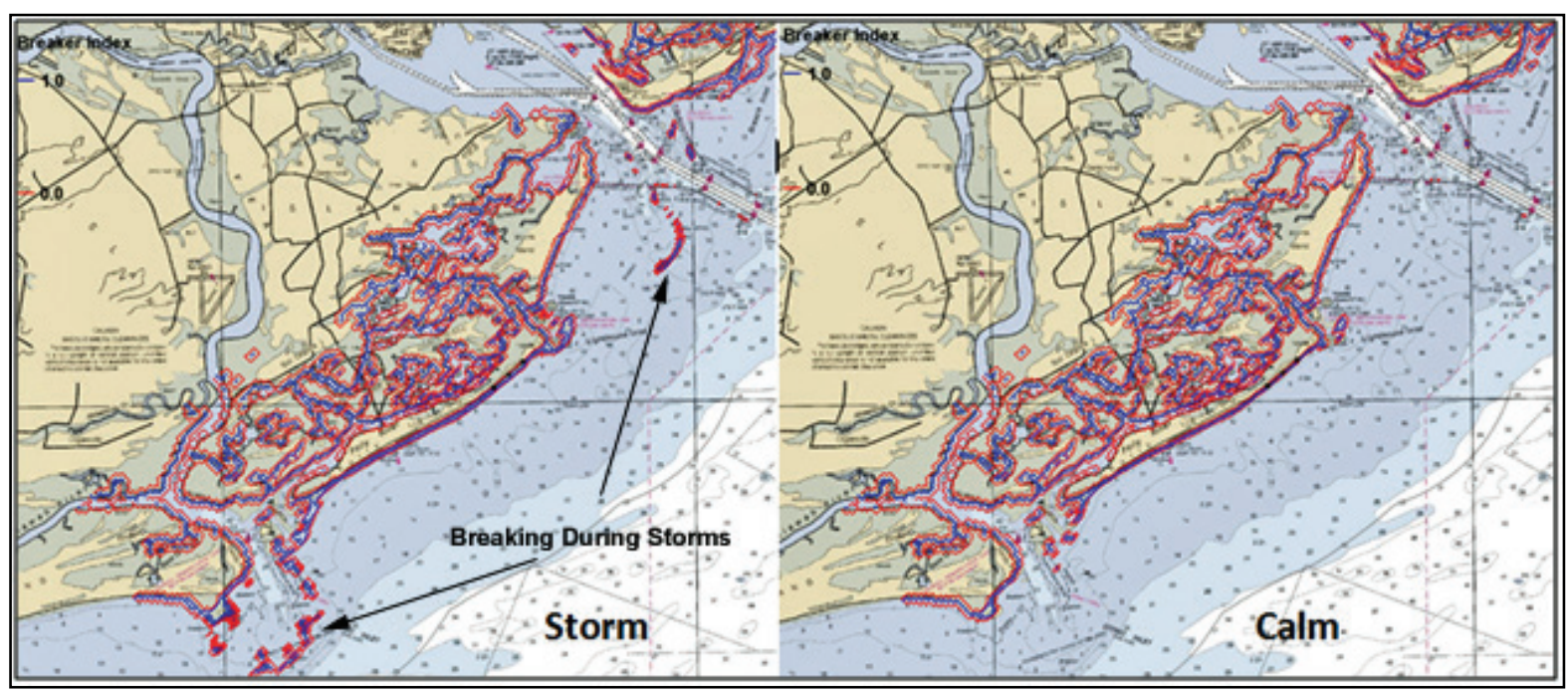

A USACE study (Hansen and Knowles 1988) estimated the average depth of breaking of a $1.1 \mathrm{~m}(3.5 \mathrm{ft})$ wave height to be a distance of $75 \mathrm{~m} \mathrm{(250} \mathrm{ft)}$ offshore from mean sea level (MSL) for Folly Island. Also, the estimated annual mean closure depth was approximately $5 \mathrm{~m}(17 \mathrm{ft})$ mean low water at Folly Island.

The stability graph developed by Hands and Allison (1991) and modified by Beck et al. (2012) shown in Figure 10 illustrates the stability of berm projects based on their depth and whether this depth is shallower or deeper as compared to the inner and outer DOC (as defined by Hands and Allison 1991) limits. The inner limit marks the seaward extent of the littoral zone where the bed experiences extreme activity caused by waves breaking and their related currents. The outer limit denotes the limit of the shoal zone where waves will cause little sediment transport and waves have neither a strong nor negligible effect on the bed (Hallermeier 1981). Hallermeier (1981) defined the equation for the inner limit as 


$$
D O C_{\text {inner }}=2 H_{s}+11 \sigma_{H s}
$$

relating the annual mean significant wave height, $H_{s}$, and the associated standard deviation of the significant wave height, $\sigma_{H s}$.

The outer limit includes a typical median sand diameter, $D$, at the project location, and is defined by Hallermeier (1981) as

$$
D O C_{\text {outer }}=\left(H_{s}-0.3 \sigma_{H s}\right) T_{s}
$$

with $T_{s}$ being the average wave period associated with the annual mean significant wave height, $H_{s}$, and $g$ being the acceleration of gravity.

Figure 10. Nearshore berm stability graph illustrating the difference between active and stable berms in deep or shallow water. (Beck et al. [2012], as modified from Hands and Allison [1991].)

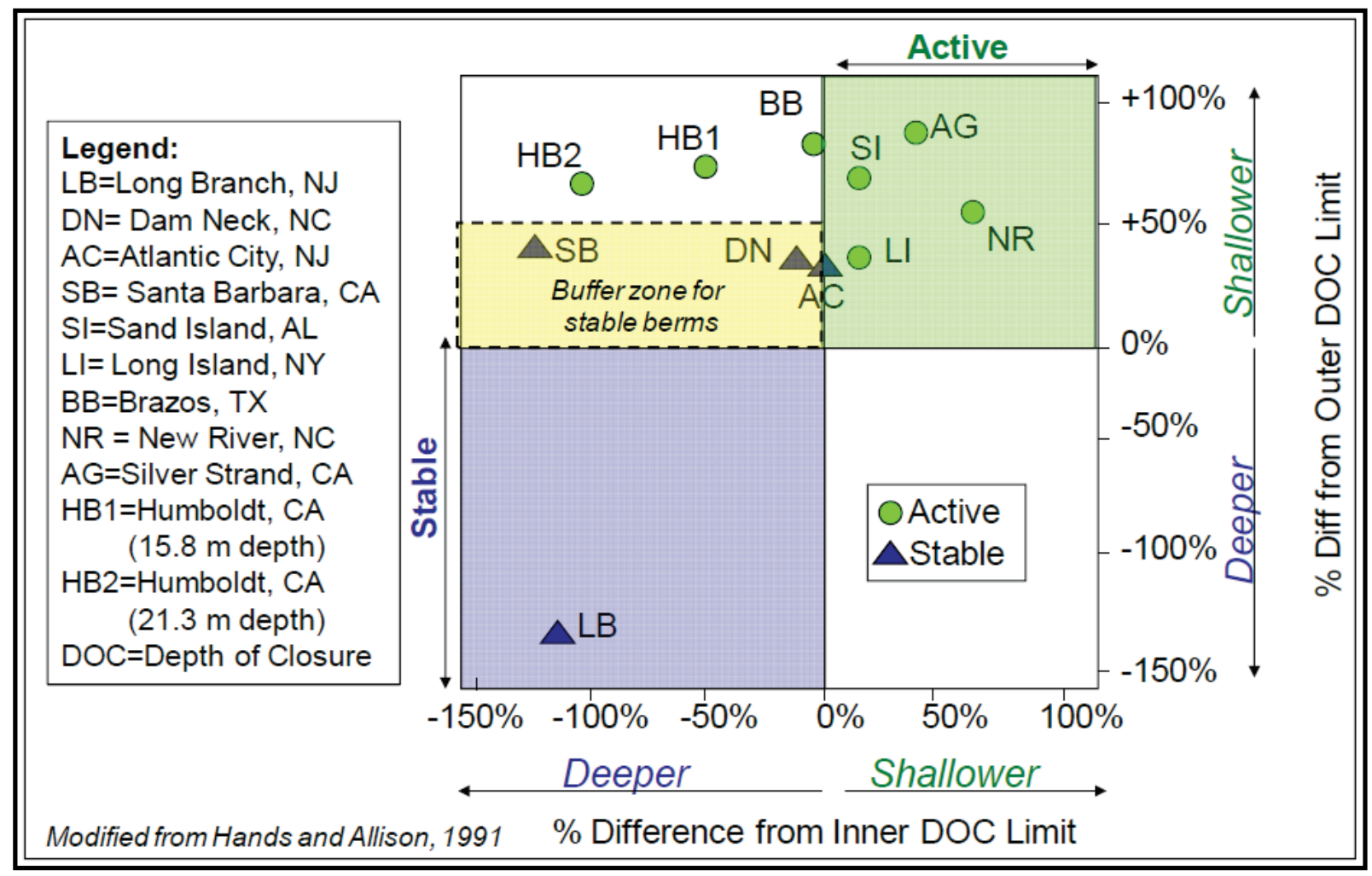

The stability graph is intended to provide information as to whether a berm will be stable or migratory (active) based on the wave data available at the time of the Hands and Allison (1991) study. The buffer zone defined by Hands and Allison (1991) (upper left quadrant of Figure 10) contained stable berms that were placed between $0 \%$ to $50 \%$ shallower than the 
outer DOC limit but still were deeper than the inner DOC limit. Berms placed in locations with less than half the water depth of the outer DOC limit tended to be active, indicating a potential cutoff point for active feeder berms (Beck et al. 2012).

Figure 11 shows the wave-height rose at the USACE Wave Information Studies (WIS) Sta. 63349 during 1980-1999. Wave hindcast data from WIS Station 63349 were used to estimate the inner and outer DOC limits as DOC $_{\text {inner }}=9.5 \mathrm{~m}(31 \mathrm{ft})$ and DOC $_{\text {outer }}=19.5 \mathrm{~m}(64 \mathrm{ft})$ MSL, respectively.

Figure 11. USACE WIS Sta. 63349 wave rose.

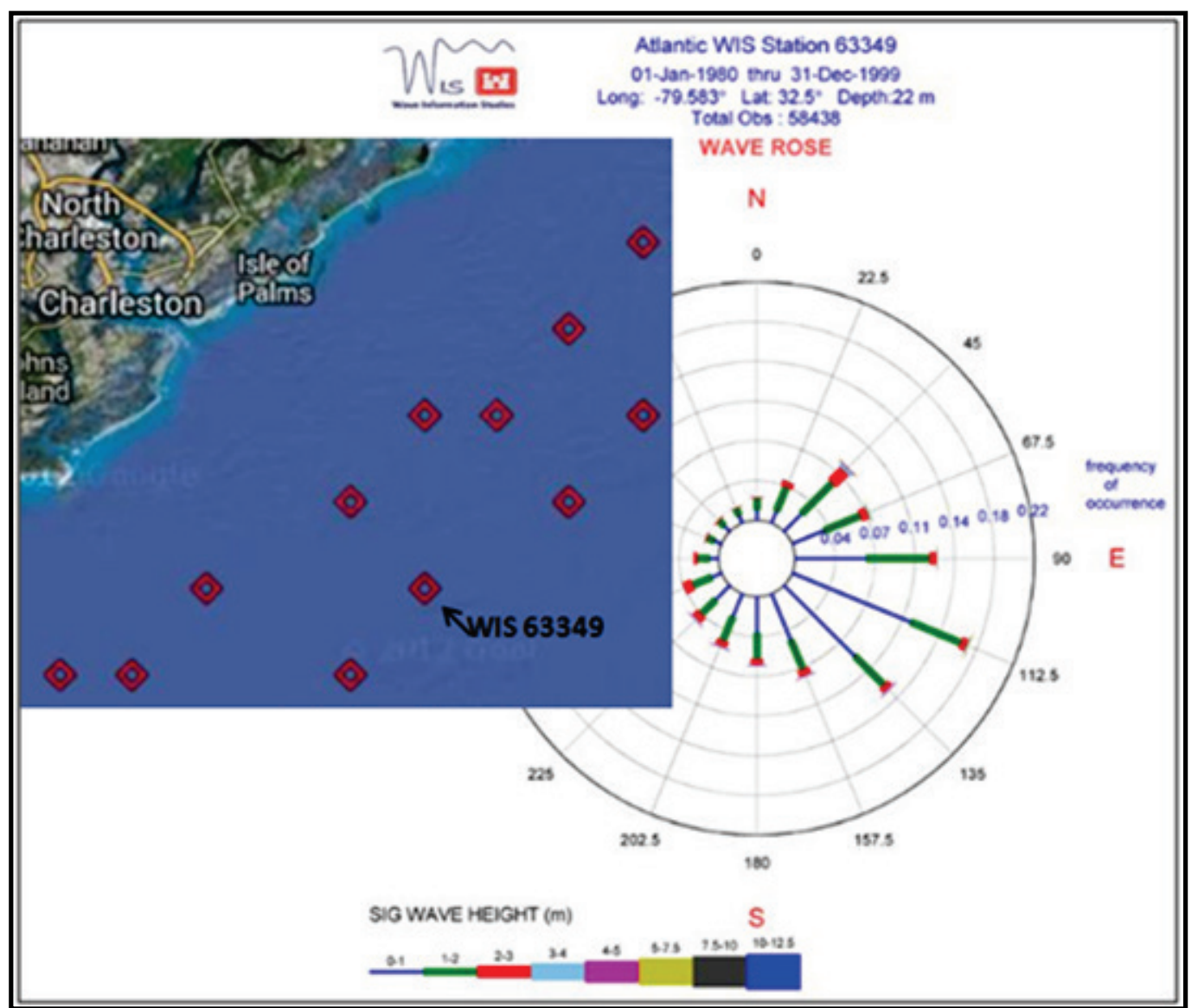

Based on a review of relevant historical data, three potential areas for nearshore placement of dredged material were selected (Figure 12) landward of the DOC. These areas were also selected based on distance from the navigation channel. According to the Hands and Allison (1991) nearshore berm stability graph, the three proposed Charleston placement areas (denoted as Areas 1, 2, and 3 in Figure 12) have a tendency to be active. This selection excludes cultural, economic, and environmental considerations. 
Figure 12. Potential areas for nearshore placement.

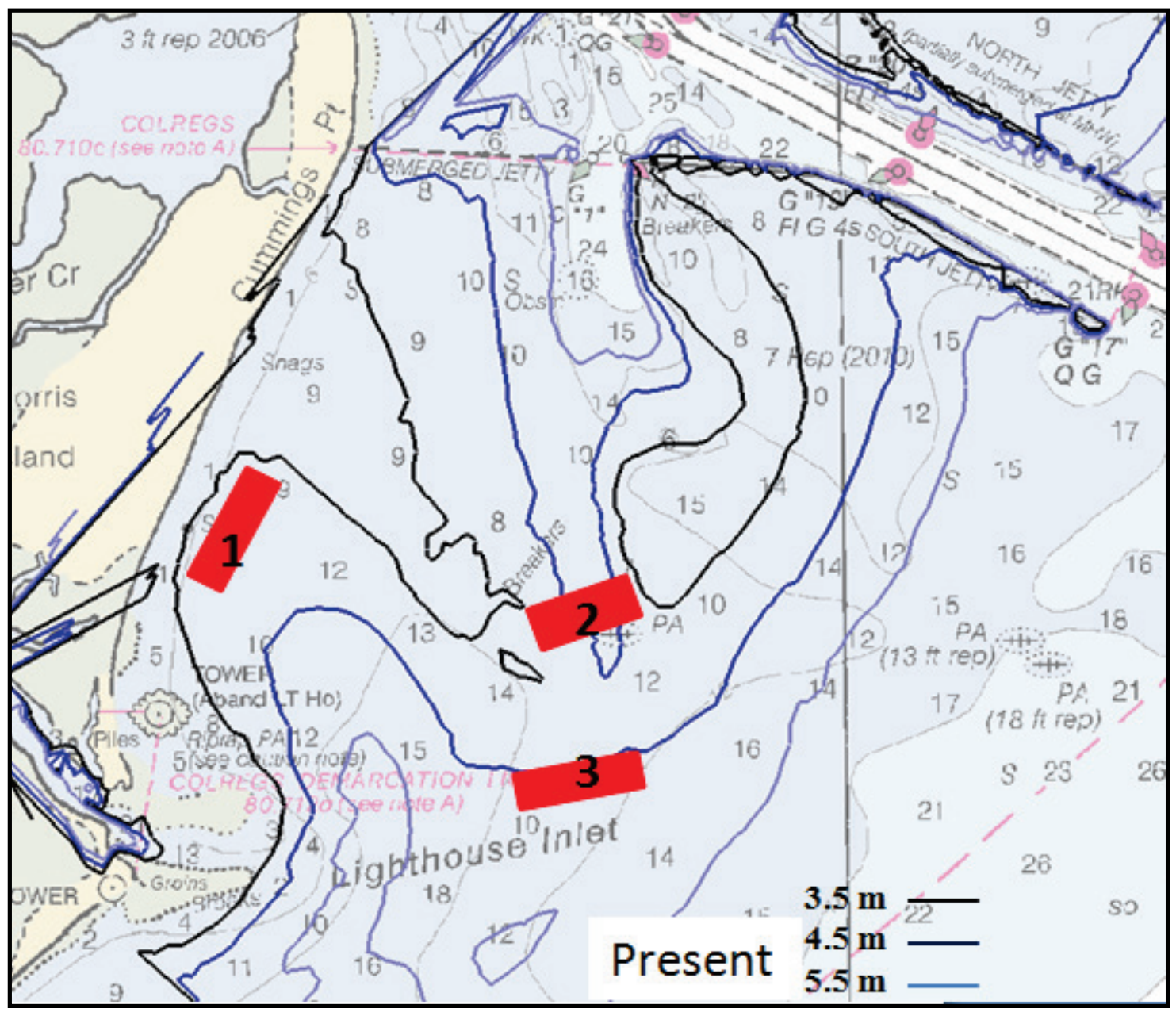

Placement Area 1 (approximate average depth $=3.5 \mathrm{~m}[11.5 \mathrm{ft}]$ ) was

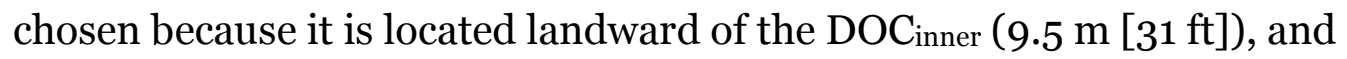
the region tends to be active, according to the Hands and Allison (1991) nearshore berm stability graph. It is expected to feed sediment toward the southern Morris Island Folly Island shorelines. It should help reduce chronic erosion along the southern stretch of Morris Island beach.

Placement Area 2 (approximate average depth $=4.5 \mathrm{~m}[14.8 \mathrm{ft}]$ ) was chosen because it is located inside the wave breaking zone and is expected to experience strong berm erosion. The region is located landward of the

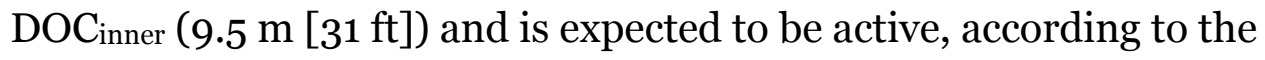
Hands and Allison (1991) nearshore berm stability graph.

Placement Area 3 (approximate average depth $=5.5 \mathrm{~m}[18.0 \mathrm{ft}]$ ) was chosen because it is also located landward of the DOC inner $(9.5 \mathrm{~m}[31 \mathrm{ft}])$ and is expected to be active, according to the nearshore berm stability graph (Hands and Allison 1991). 


\section{Simulation Periods}

Time-series of measured wave height at the Offshore ADCP during November 2012-July 2013 were analyzed to select representative incident wave conditions at the study region to drive the CMS-Wave simulations. The period of 5-30 December 2012 was selected for active winter conditions while 10 May-5 June 2013 was selected for the calm summer condition. Figures 13 and 14 show the time-series of wave height at the Offshore $\mathrm{ADCP}$ for the selected active winter and calm summer conditions, respectively. Hourly wind data were obtained from the National Data Buoy Center (NDBC) Buoy 41029. Missing wind data at NDBC Buoy 41029 were replaced by data from NDBC Station FBIS1 (Figure 15). Missing wave data at the Offshore ADCP were interpolated since the missing wave data did not occur at the peak of any high wind event. The model used wave data every 3 hours (hr), and missing wave data were estimated from adjacent data.

Figure 13. Wave height at the Offshore ADCP during the selected active winter period.

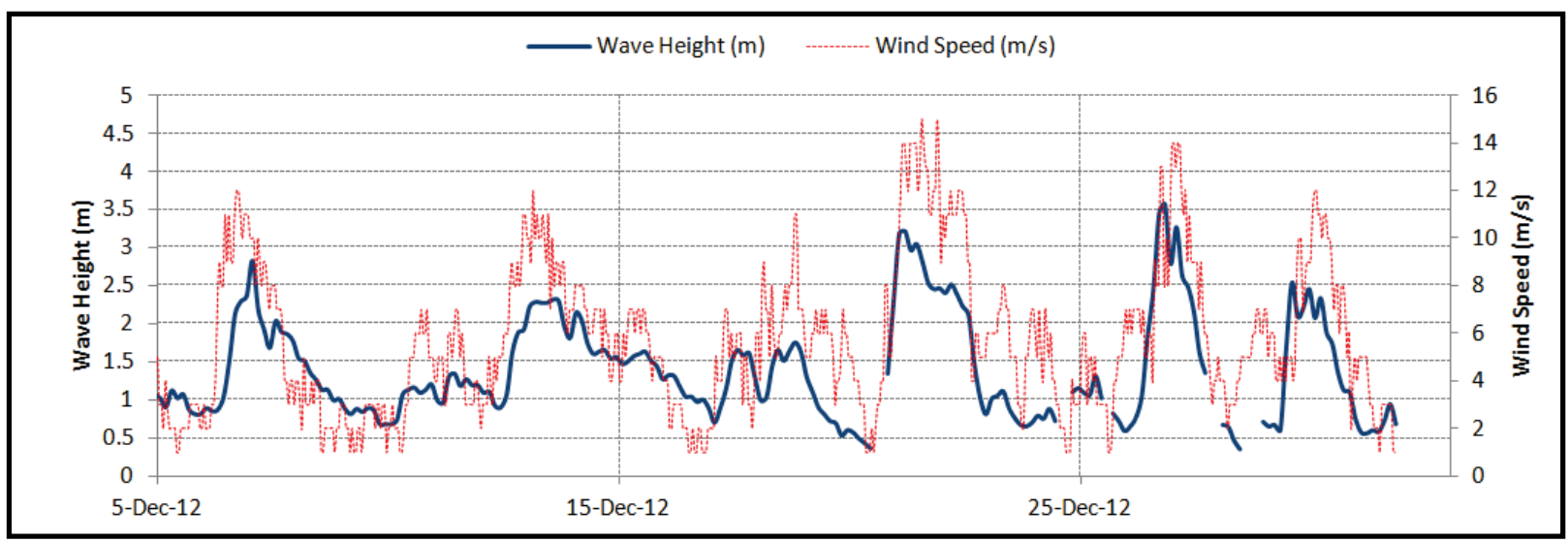

Figure 14. Wave height at the Offshore ADCP during the selected calm summer period.

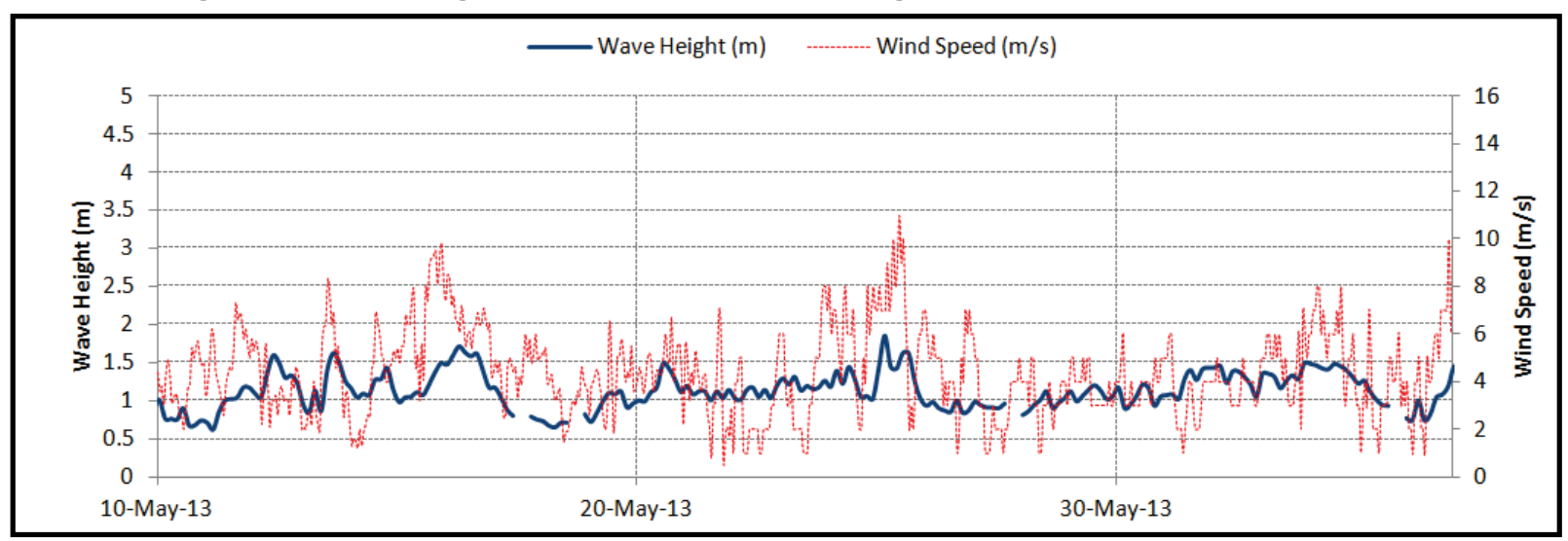


Figure 15. Location map of coastal wind stations.

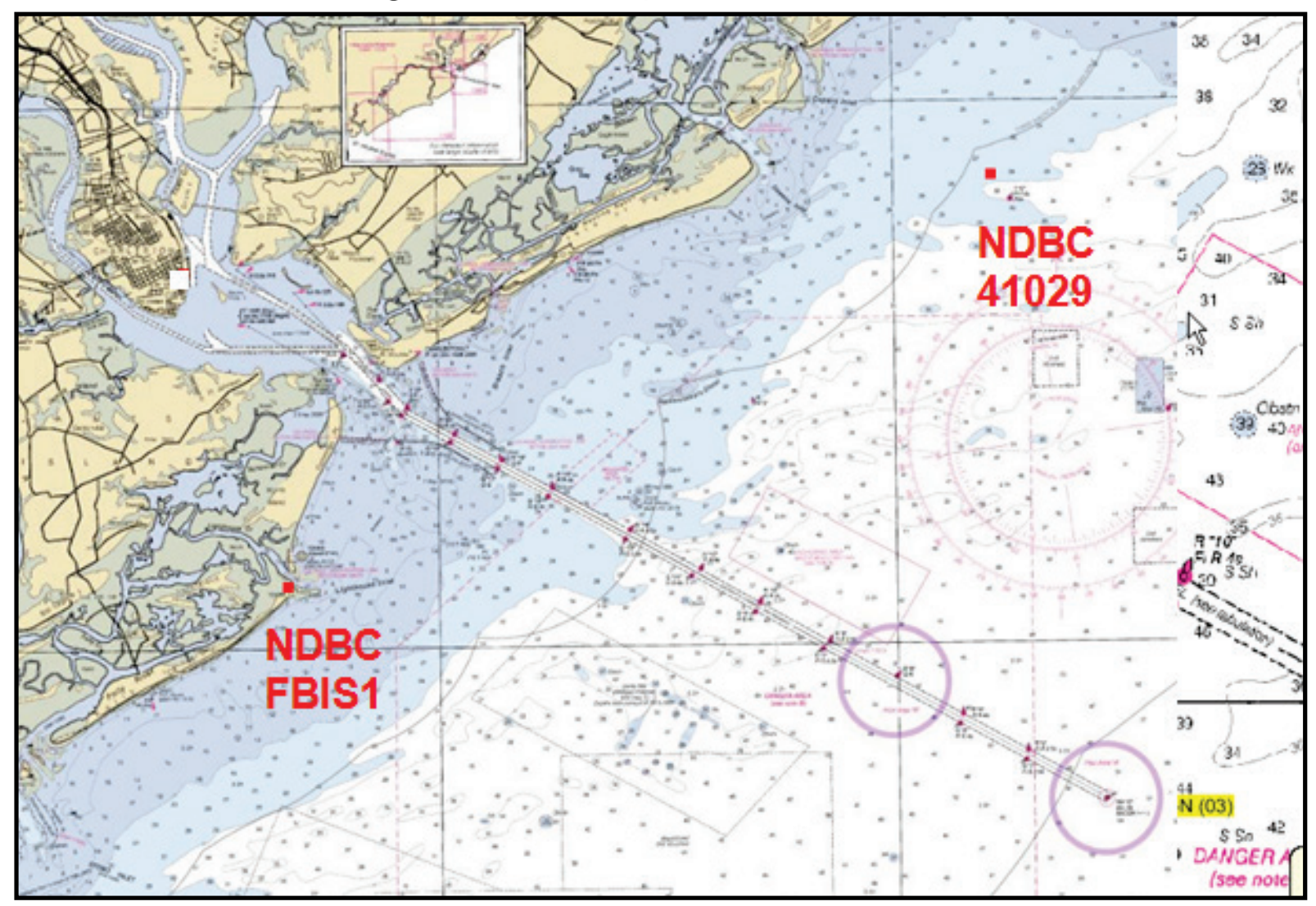




\section{Coastal Modeling System (CMS) Modeling}

CMS-Flow (Buttolph et al. 2006; Sanchez et al. 2011a, b; 14a, b) and CMSWave (Lin et al. 2008, 2011) models from the USACE Coastal Modeling System (CMS) that were developed and applied previously for the Charleston Harbor numerical modeling study (Kashlan 2013) were used in this study.

The CMS is an integrated suite of numerical models consisting of a hydrodynamic and sediment transport model (CMS-Flow) and a spectral wave model (CMS-Wave) and can be coupled with a PTM (Demirbilek et al. 2008). The coupled modeling system calculates time-dependent watersurface elevation, current speed and direction, waves, sediment transport, and morphology change in coastal and inlet applications. All pre- and post-processing for these models is performed within the USACE SMS interface (Lin et al. 2011). The framework of CMS is shown in Figure 16.

Figure 16. The USACE CMS framework and its components (Demirbilek and Rosati 2011).

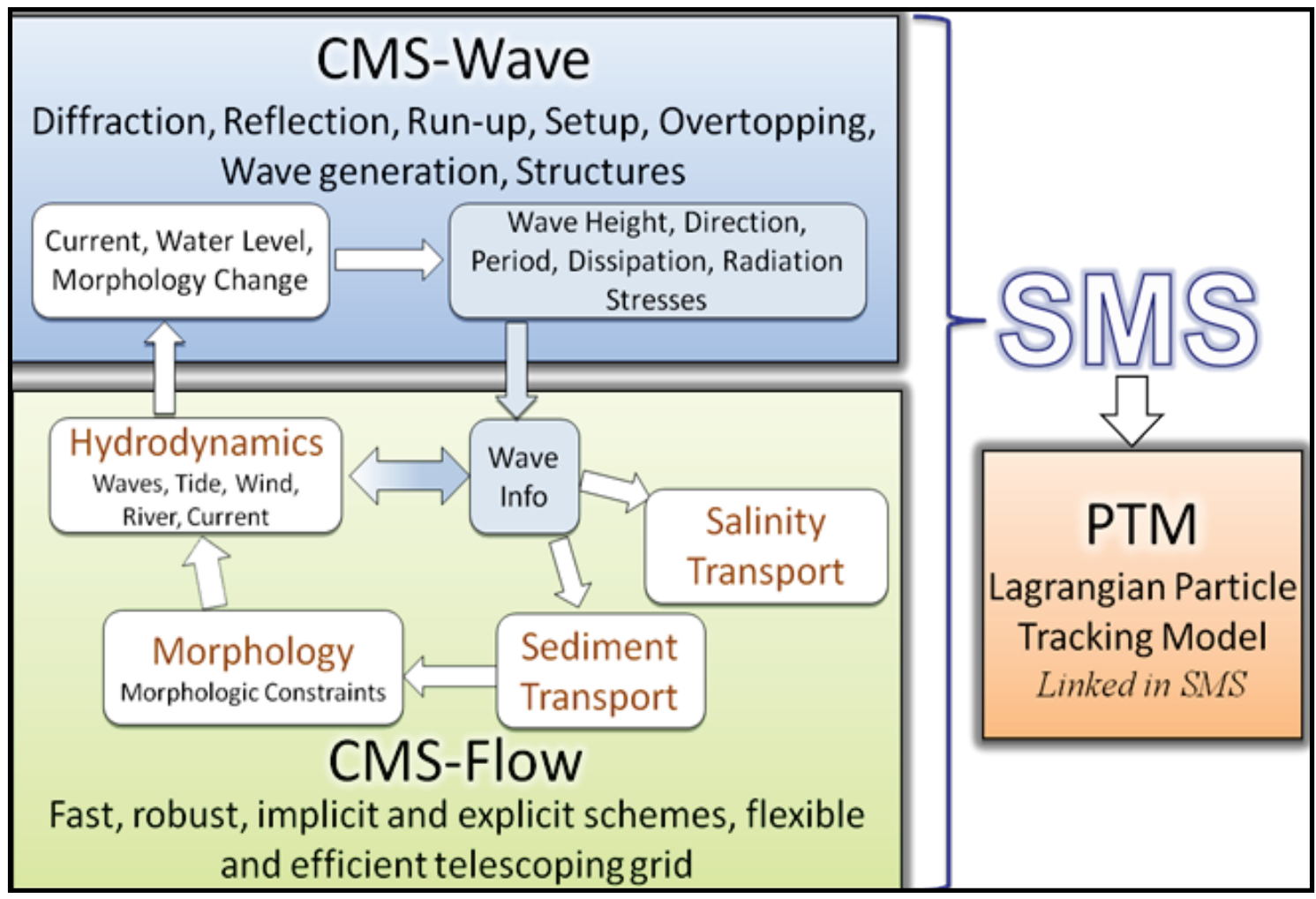


CMS-Flow is a two-dimensional, depth-integrated (2-D), finite-volume model that solves the mass conservation and shallow-water momentum equations of motion on a non-uniform Cartesian grid. Wave radiation stresses and other wave parameters are calculated by CMS-Wave and supplied to CMS-Flow for hydrodynamic and sediment transport calculations through the steering module.

CMS-Wave is a 2-D spectral wave transformation model that solves the steady-state wave-action balance equation on a non-uniform Cartesian grid. The model is designed to simulate wave processes that are important in coastal inlets, in the nearshore zone, in the vicinity of jetties and breakwaters, and in ports and harbors. These processes include wave shoaling, refraction, diffraction, reflection, wave breaking and dissipation, wave-structure and wave-current interactions, and wave generation and growth mechanisms.

The hydrodynamic, wave, and sediment numerical models simulated the coastal processes in the Charleston coastal region and impacts to the jetties and Morris Island disposal region. Model calibration and verification were completed in the previous study (Kashlan 2013). These models provide better management of the Charleston Harbor Entrance Channel dredged sediment. The present modeling effort adapted the same models with finer grid resolution at the potential dredged material placement areas. The overall bathymetry was left the same, except for alterations due to the placement alternatives mounds. Bathymetry alterations due to channel deepening in the Charleston Harbor Entrance Channel were not considered in this study. Figure 17 shows the CMS-Flow and CMS-Wave model domains.

The CMS-Flow was forced at the ocean boundary with time-series of water level extracted from the U.S. East Coast Tidal Database (EC2001) by the USACE Advanced CIRCulation (i.e., ADCIRC) model (Mukai et al. 2002). 
Figure 17. CMS-Flow (blue) and CMS-Wave (red) model domains, Charleston Harbor Entrance Channel.

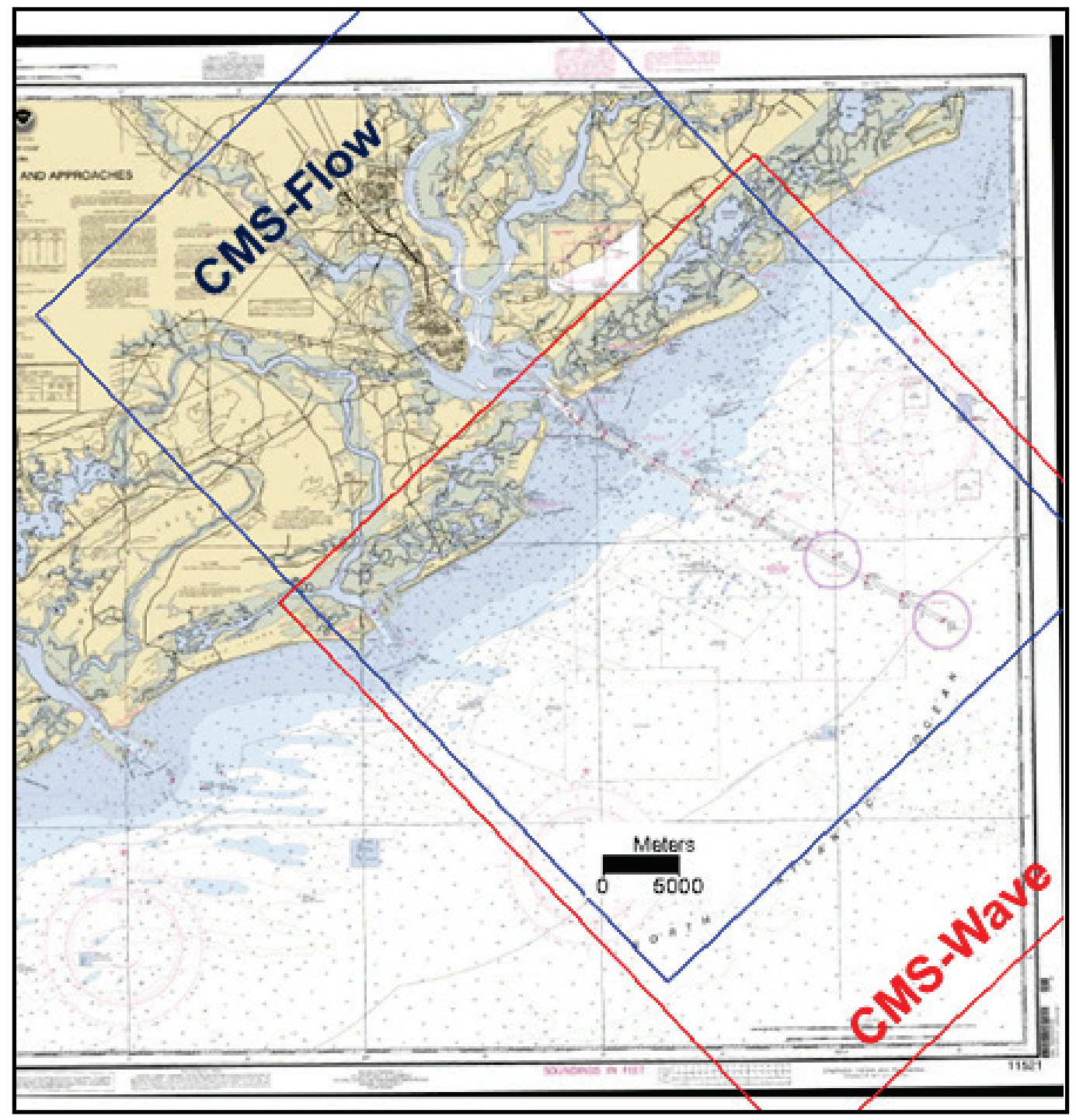

\section{Model setup}

Figure 18 shows the CMS-Flow and CMS-Wave grid resolution at the three potential placement areas.

The inline version of CMS-Flow, which includes CMS-Flow and CMS-

Wave in one code, was adopted in the present study because of its capability to implement the tidal constituent forcing at the ocean boundary for the telescoping CMS-Flow grid. The surface roller model was activated in CMS-Flow. As a wave transitions from nonbreaking to fully breaking, part of the energy is converted into momentum, which goes into the aerated region of water known as the surface roller. Under the assumption that the surface roller moves in the mean wave direction, the 
evolution and dissipation of the surface roller energy is calculated by an energy balance equation. It is recommended to always turn on the surface roller model (Sanchez et al. 2011b).

Figure 18. Increased grid resolution within the three potential placement areas.

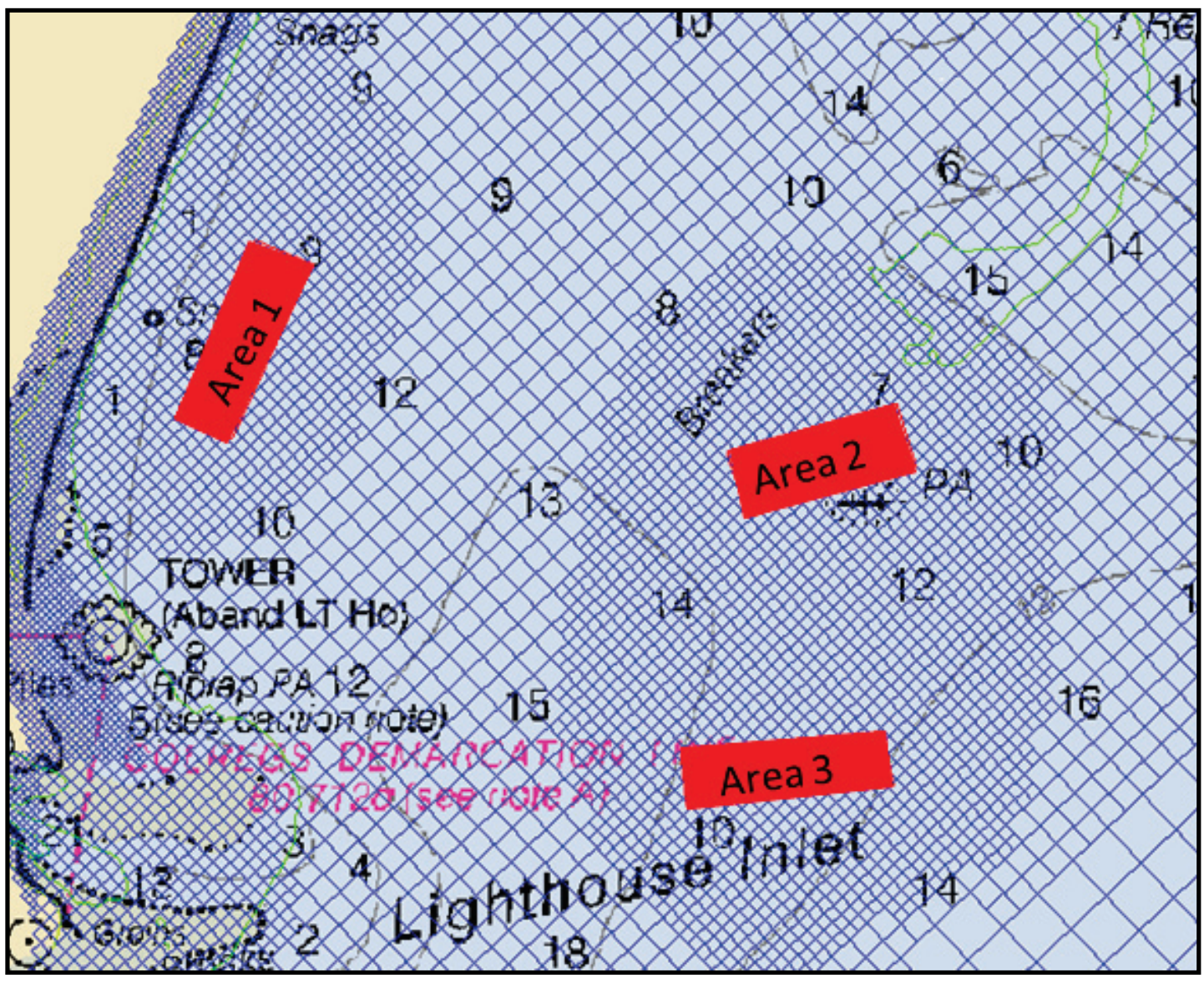

Figure 19 shows the location of the U.S. Geological Survey (USGS) gauges for flows of the three major rivers discharging into Charleston Harbor.

CMS-Flow was forced with the following:

- Time-series of water level extracted from the EC2001 tidal database.

- Hourly wind measurements at NDBC Buoy 41029.

- Constant monthly average river flow rates of $12.37,286.0$, and 44.46 cubic meters/second (m3/sec) (437, 10, 100, and 1,570 cubic feet/second [ft3/sec]) at Ashley, Cooper, and Wando rivers, respectively, during the active winter period, and monthly average flow rate of 11.1, 197.65, and $22.9 \mathrm{~m} 3 / \mathrm{sec}(390,6,975$, and $810 \mathrm{ft} 3 / \mathrm{sec})$ at Ashley, Cooper, and Wando rivers, respectively, during the calm summer period. 
Figure 19. Location map of the USGS flow gauges on the Ashley, Cooper, and Wando Rivers.

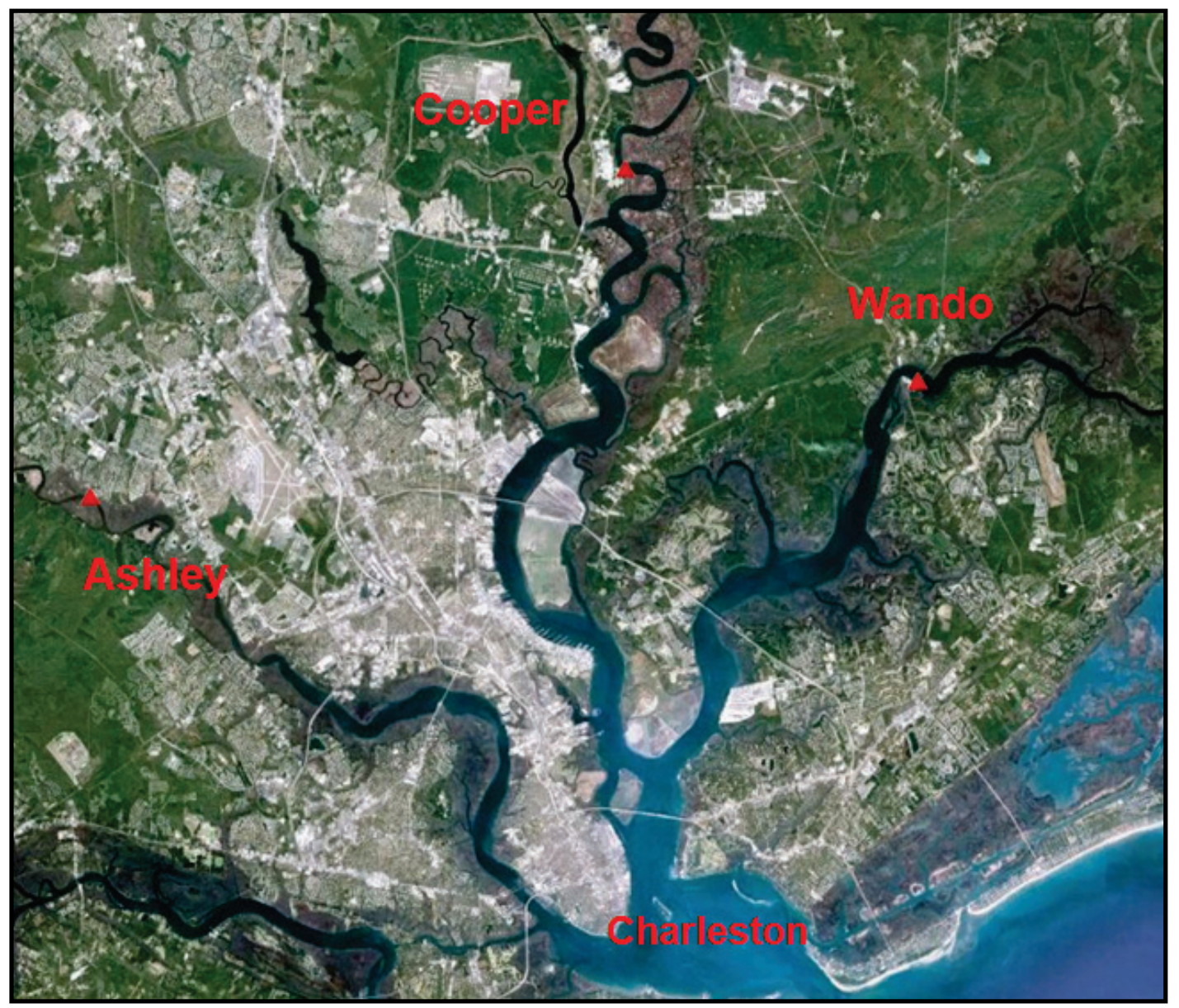

CMS-Wave was forced with EPA Offshore ADCP wave spectra every $3 \mathrm{hr}$ at the model offshore boundary. Directional data in 7 frequency bands and non-directional data in 128 bands were obtained at the Offshore ADCP. Software prepared by the U.S. Army Engineer Research and Development Center (ERDC) ${ }^{1}$ as used to generate the wave input file.

The Non-Equilibrium Transport model (Sanchez and Wu 2011), which is based on a total load advection-diffusion approach, was adopted to estimate sediment transport. The van Rijn transport formula was used as the governing empirical equations to calculate bed load and suspended load within CMS-Flow for combined waves and current. The default CMS suspended load and bed load sediment transport scaling factors were applied.

\footnotetext{
${ }^{1}$ L. Lin, ERDC, personal communication, May 2014.
} 
The median sediment grain size $\left(\mathrm{D}_{50}\right)$ values were based on the UISSEABED database of the USGS and the University of Colorado (http://walrus.wr.usgs.gov/usseabed/) to present the spatial distribution of sediment used in the modeling. A spatially variable grain size between $0.10-0.18$ millimeter (mm) (0.004-0.007 inch (in.]) was adopted in the CMS-Flow model (Kashlan 2013). A Darcy-Weisbach friction coefficient of 0.007 and diffraction intensity of 4 were adopted for the CMS-Wave model (Kashlan 2013). These values were determined to be appropriate for calibrating the model.

The CMS simulations were conducted to calculate the sediment transport using tide, wind, and wave forcing during the representative active and calm weather periods. The simulations included the existing configuration and the three nearshore dredged material placement potential areas.

A constant sediment volume of $400,000 \mathrm{~m}^{3}\left(523,000 \mathrm{yd}^{3}\right)$ of new work dredging from the Charleston Harbor Entrance channel was specified for each placement area. A rectangular region with $2 \mathrm{~m}(6.6 \mathrm{ft})$ thickness above the existing seabed was specified inside the three proposed placement areas. Table 3 shows the footprint of each proposed placement area.

The existing CMS-Flow and CMS-Wave grids bathymetry were modified at the three proposed placement areas by reducing the depth of grid cells inside the rectangular placement areas by $2.0 \mathrm{~m}(6.6 \mathrm{ft})$. Simulations were conducted with the modified bathymetry at each area during the active winter and calm summer periods.

Table 3. Potential placement areas footprint.

\begin{tabular}{|l|l|}
\hline Placement Area & Footprint \\
\hline Area1 & $255 \mathrm{~m} \times 790 \mathrm{~m}$ \\
& $(835 \mathrm{ft} \times 2,600 \mathrm{ft})$ \\
\hline Area 2 & $280 \mathrm{~m} \times 725 \mathrm{~m}$ \\
& $(920 \mathrm{ft} \times 2,380 \mathrm{ft})$ \\
\hline \multirow{2}{*}{ Area 3 } & $235 \mathrm{~m} \times 860 \mathrm{~m}$ \\
& $(770 \mathrm{ft} \times 2,820 \mathrm{ft})$ \\
\hline
\end{tabular}

\section{Model validation}

Figure 20 shows the comparison between measured and modeled wave height at RSM-S ADCP for 5-31 December 2012 with the existing bathymetry. 
Figure 20. Comparison of measured and modeled wave height at RSM-S ADCP during active winter simulation period.

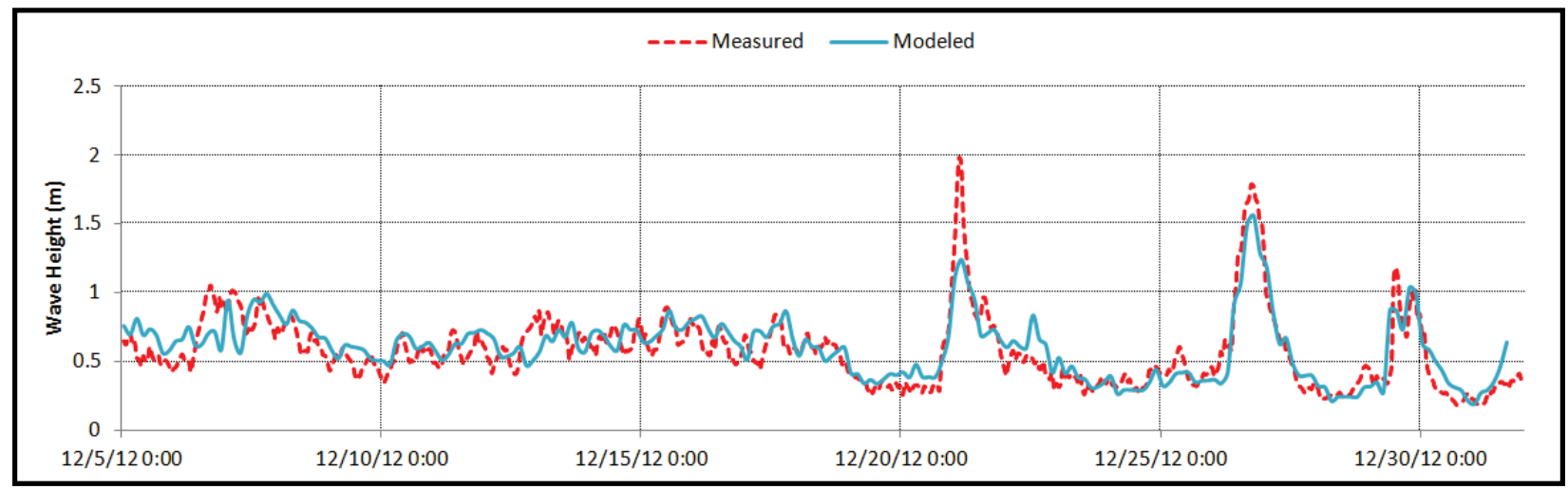

A MATLAB routine, prepared by ERDC, was used to calculate the principal current component axes of U (east-west) and V (north-south) vector timeseries data. This subroutine is useful for determining the main direction of fluid flow and extracting the velocity component along the major axis. The principal axes are determined by solving the Eigen value problem for 2-D scatter data. Measured and modeled current data are aligned mainly with flood-ebb major or principal axis of approximately 130.7 degree (deg) and 128.9 deg directions, respectively.

Measured current data time-series were filtered with a low-pass filter using two cycles per day to mostly retain tidal motion. USACE (2013) includes details of the CMS models calibrations. Figure 21 shows the comparison between measured, modeled, and filtered principal current components at RSM-S ADCP for 5-31 December 2012.

The index of agreement (IA) (USACE 2015) was used to calculate model performance, where

$$
\mathrm{IA}=1-\frac{\sum_{i=1}^{n}\left(O_{i}-P_{i}\right)^{2}}{\sum_{i=1}^{n}\left(\left|P_{i}-\bar{O}\right|+\left|O_{i}-\bar{O}\right|\right)^{2}}
$$

Here, $P$ is the predicted value, $O$ is the observed value, and $n$ is the number of data points. IA is a standard measure of the degree of simulation error, with 1.000 being a perfect match. The IA between the measured and modeled filtered water current data was 0.935 . 
Figure 21. Comparison of measured, modeled, and filtered principal current at RSM-S ADCP during active winter simulation period. Positive currents are during the flooding tide; negative currents are during the ebbing tide.

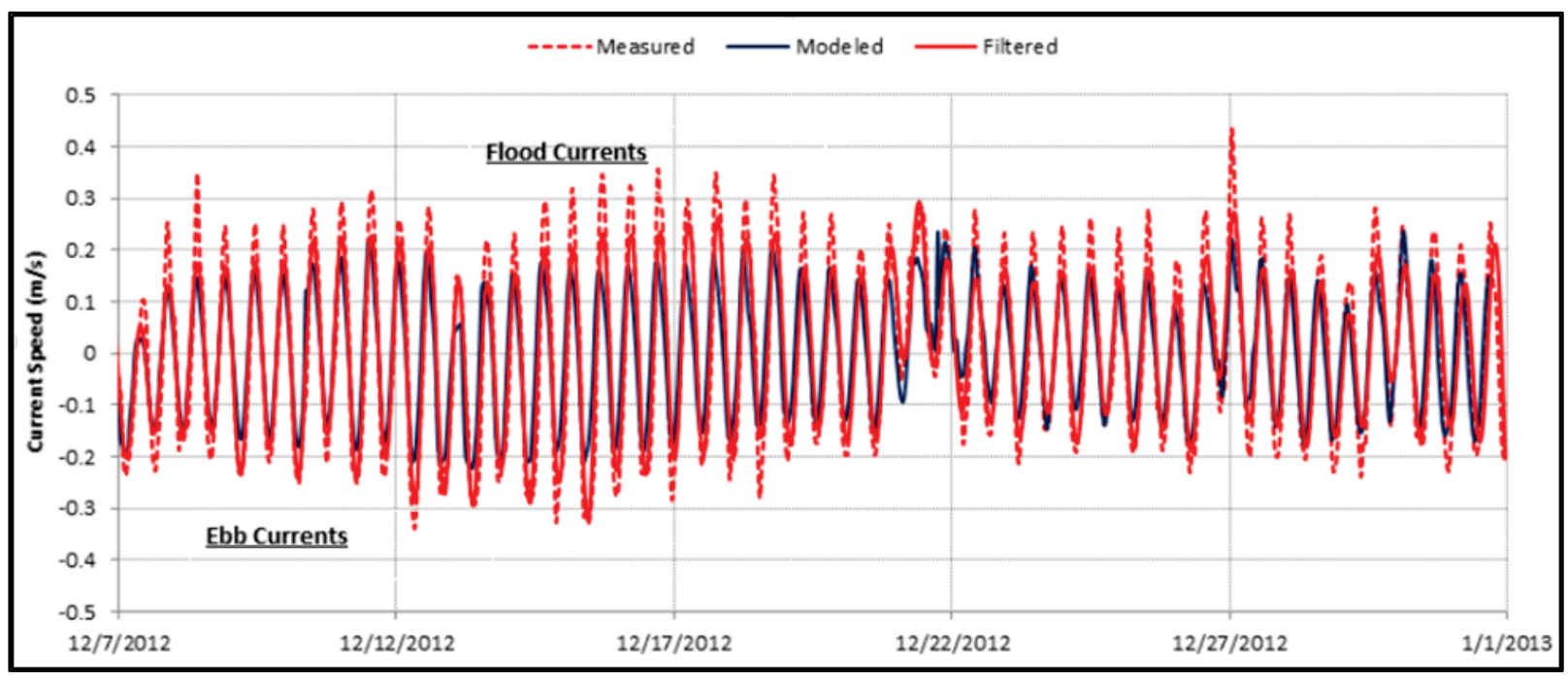

Model simulation was conducted for 10 May to 4 June 2013 with the existing bathymetry. Figure 22 shows the comparison between measured and modeled wave height at RSM-S ADCP.

Figure 22. Comparison of measured and modeled wave height at RSM-S ADCP during calm summer simulation period.

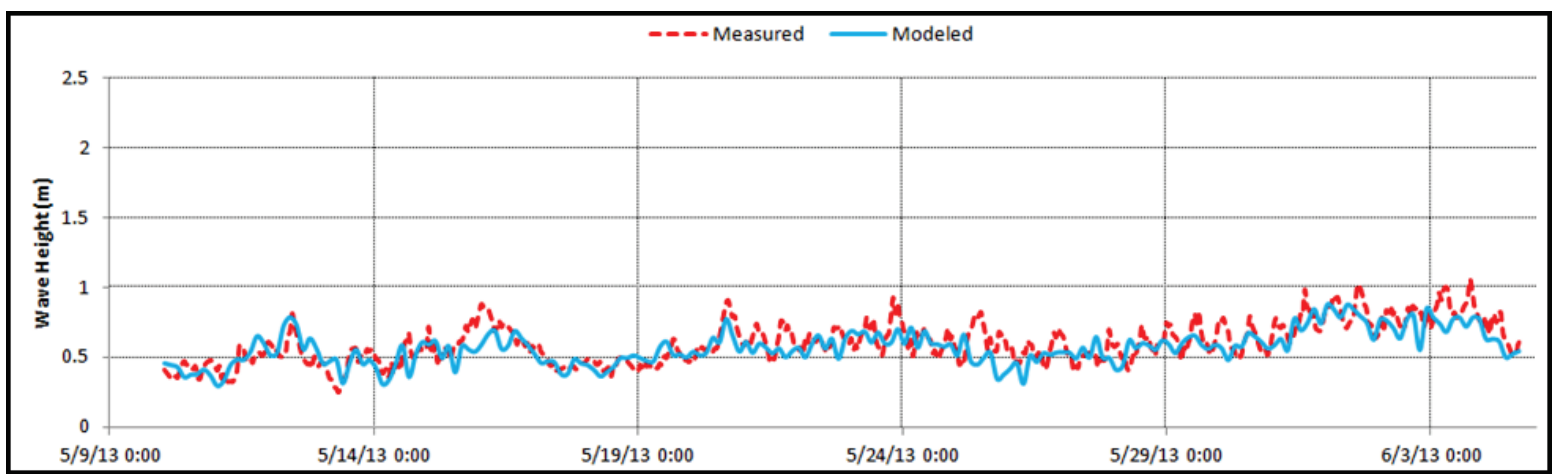

Measured and modeled current data are aligned mainly with flood-ebb major or principal axis of approximately $139.9 \mathrm{deg}$ and $136.2 \mathrm{deg}$, respectively. Figure 23 shows the comparison between measured, modeled, and filtered principal current components at RSM-S ADCP for 10 May to 4 June 2013. The IA between the measured and modeled filtered water current data was 0.961.

Measured and modeled current components agree in trend and in the orientation of the ebb-flood axis. The discrepancy in magnitude is mainly attributed to inaccuracy in the forcing tidal constituents and wind data. 
Figure 23. Comparison of measured and modeled principal current at RSM-S ADCP during calm summer simulation period. Positive currents are during the flooding tide; negative currents are during the ebbing tide.

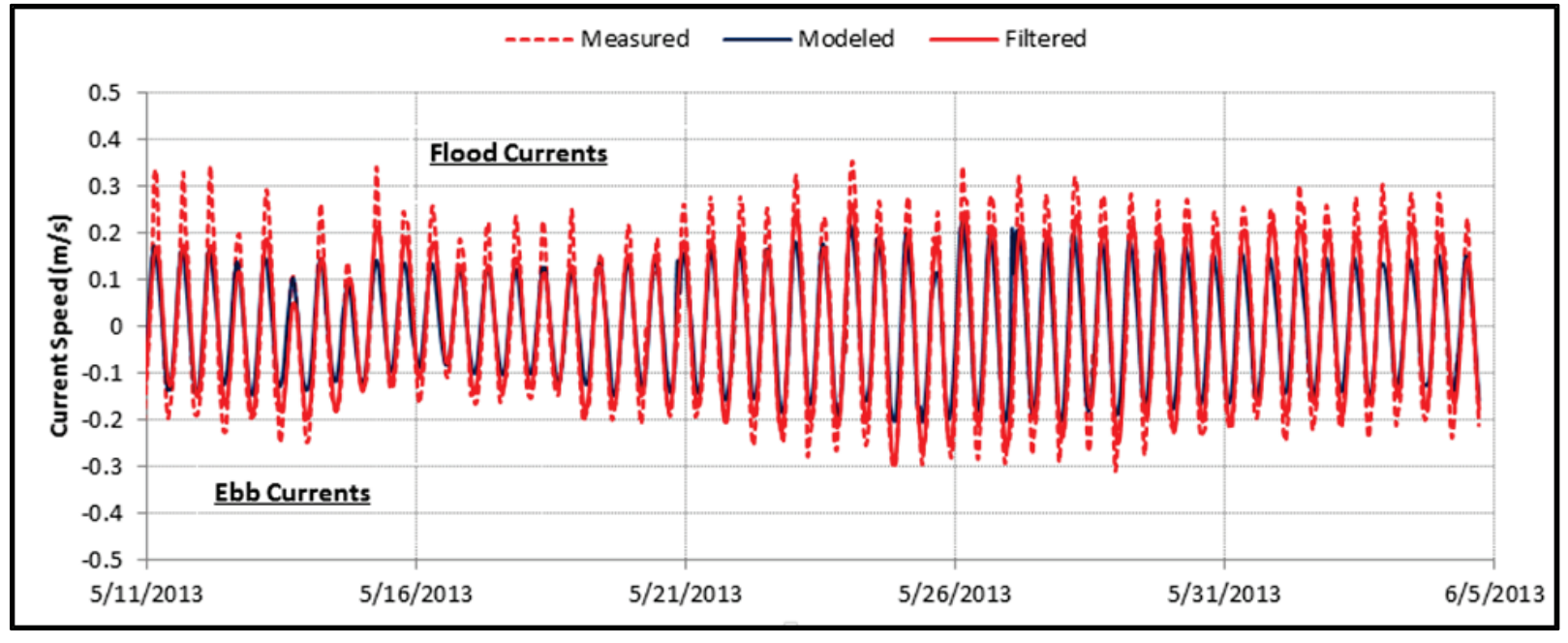




\section{Morphology Change}

CMS-Flow and CMS-Wave models were used to estimate sediment transport patterns before and after placement of dredged material in the three proposed placement areas. Morphology change was calculated at the end of the active winter simulation for the existing condition and each placement area configuration.

Figure 24 shows the morphology change in the Charleston Harbor vicinity at the end of the active winter simulation period for the existing configuration. The warmer colors in this figure represent erosion, and cooler colors represent deposition. Figures 25 through 27 show the morphology change with the $400,000 \mathrm{~m}^{3}\left(523,000 \mathrm{yd}^{3}\right)$ of dredged material placement at each area, at the end of the active winter period. Model results show similar erosion and accretion patterns in the Charleston Harbor vicinity for the existing condition and the three proposed placement areas. The figures mainly show that sediment eroded inside the proposed placement areas and accreted around the boundaries.

Figure 24. Morphology change at end of active winter period for existing condition.

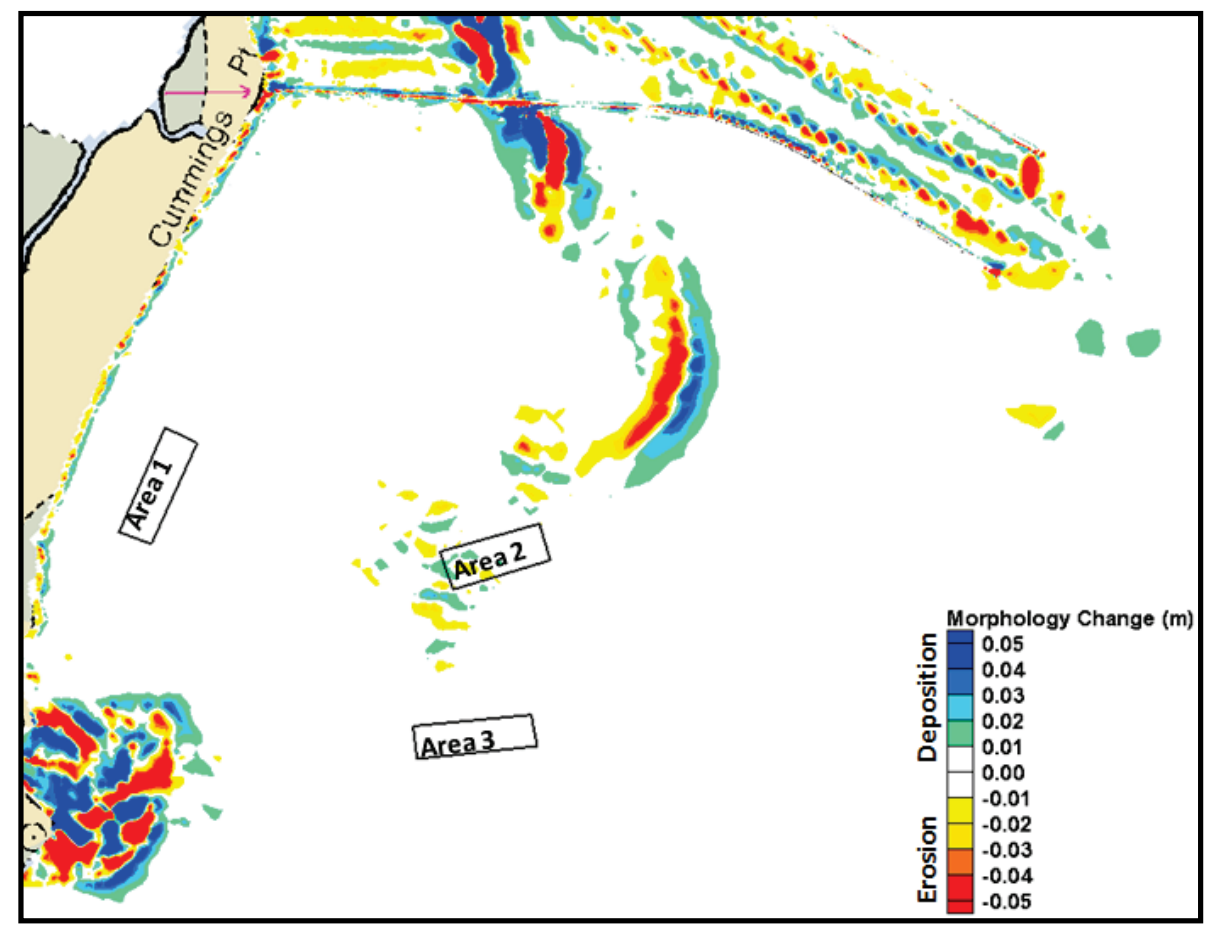


Figure 25. Morphology change at end of active winter period for placement at Area 1.

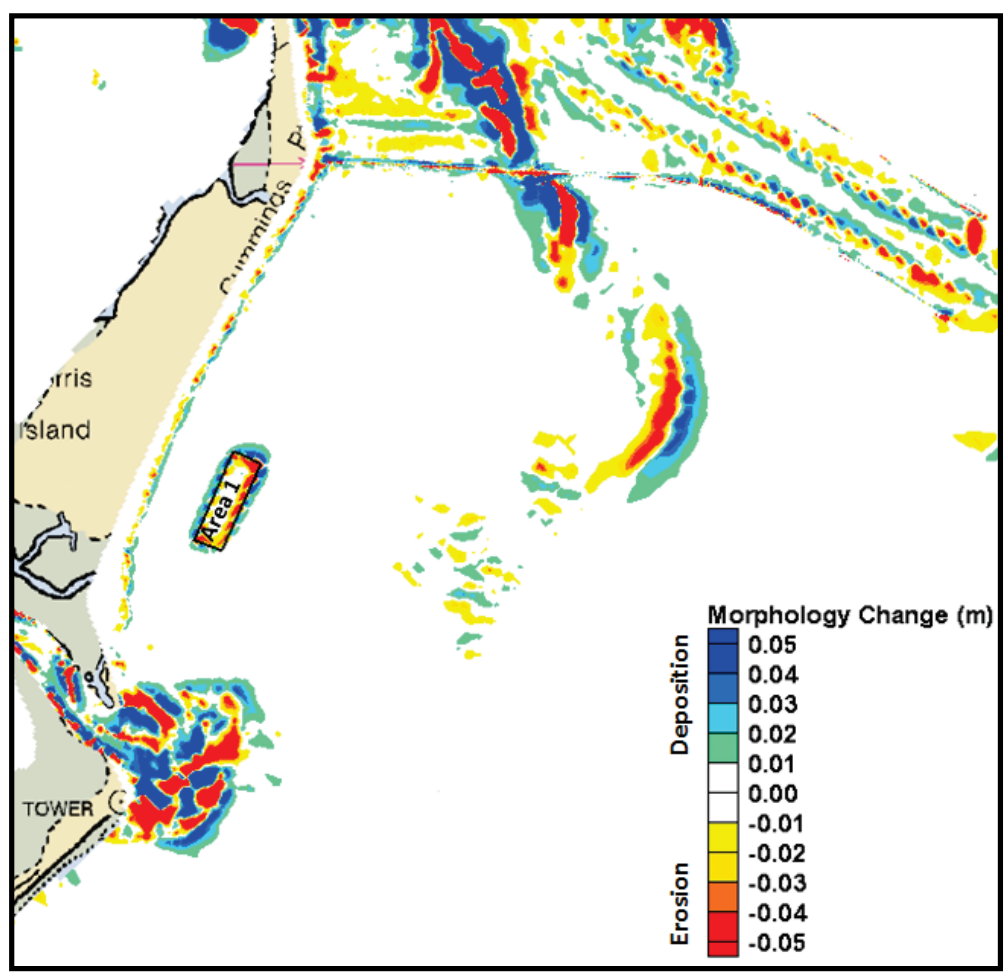

Figure 26. Morphology change at end of active winter period for placement at Area 2.

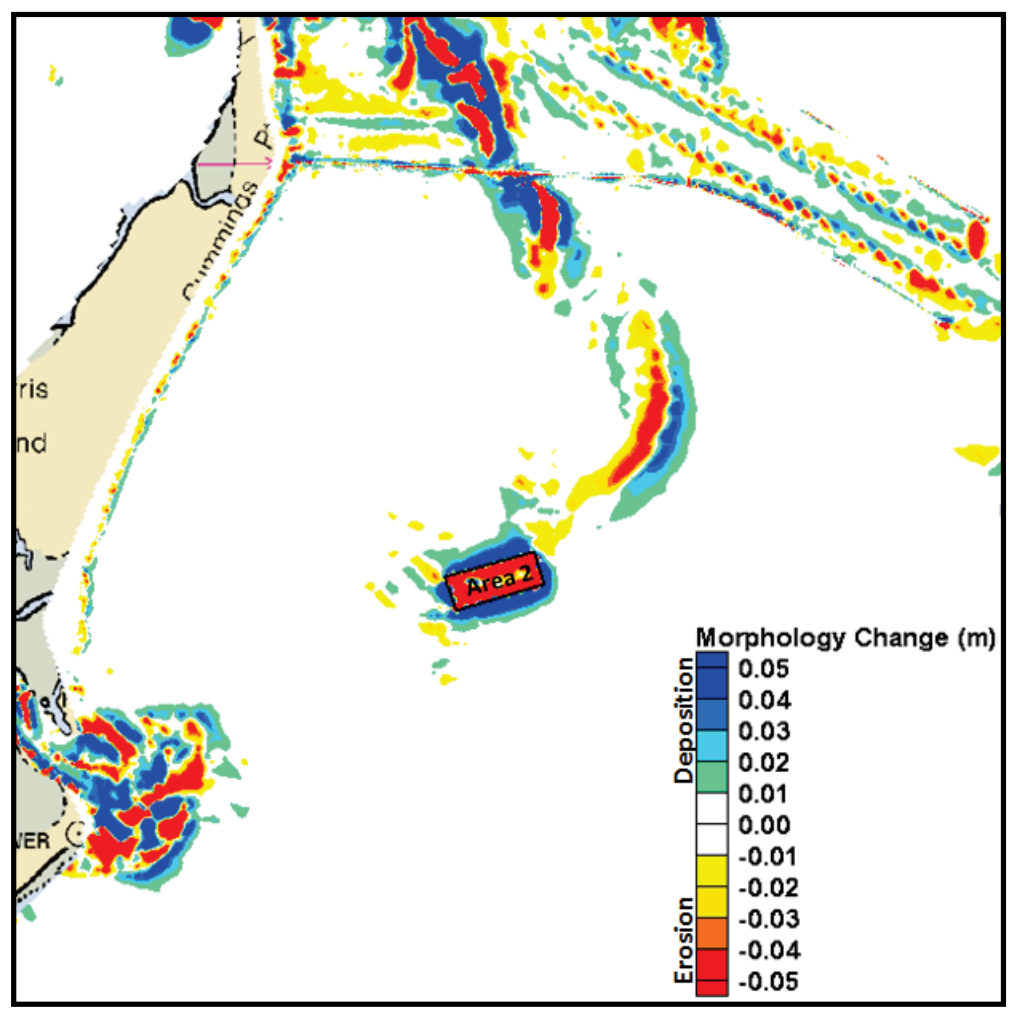


Figure 27. Morphology change at end of active winter period for placement at Area 3.

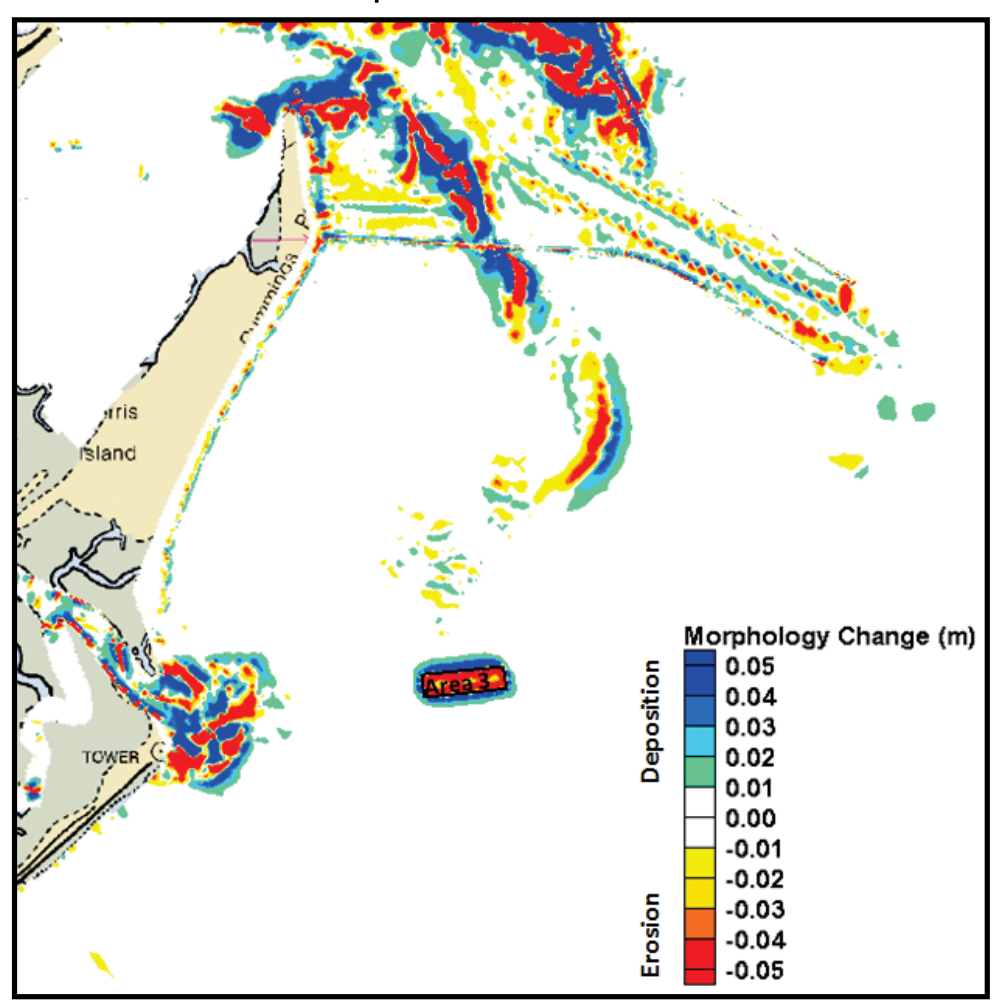

Net volume change is calculated as the volume of material lost or gained in the placement area. The net volume change provides complementary information for understanding the overall movement of material at the placement areas (USACE 2012). Table 4 shows the calculated net volume change over the active winter and calm summer periods within the proposed placement areas, with the $400,000 \mathrm{~m}^{3}\left(523,000 \mathrm{yd}^{3}\right)$ of dredged material placed in each area. Calculated net volume change at the end of the active winter and calm summer periods for the existing configuration at the proposed placement areas is given in parentheses in Table 4. For both the active winter and calm summer periods, minimal net sediment gain was observed at the three proposed placement areas for the existing condition configuration. For the active winter period, net sediment erosion volume losses occurred at all three proposed placement Areas 1, 2, and 3 of $1.4 \%, 6.0 \%$, and $3.7 \%$, respectively, of the $400,000 \mathrm{~m}^{3}(523,000 \mathrm{yd} 3)$ placement material. Maximum sediment erosion was observed within Area 2. 
Table 4. Net volume change over active winter period, and calm summer period, with the $400,000 \mathrm{~m}^{3}\left(523,000 \mathrm{yd}^{3}\right)$ of dredged material placement at each proposed area.

\begin{tabular}{|l|l|l|}
\hline \multirow{2}{*}{ Placement Area } & \multicolumn{2}{|c|}{ Net Volume Change* } \\
\cline { 2 - 3 } & Active Simulation Period & Calm Simulation Period \\
\hline $\begin{array}{l}\text { Proposed Area 1 } \\
\text { (Existing configuration) }\end{array}$ & $-5,515 \mathrm{~m}^{3}\left[7,210 \mathrm{yd}^{3}\right]$ & $-2,480 \mathrm{~m}^{3}\left[3,240 \mathrm{yd}^{3}\right]$ \\
\hline $\begin{array}{l}\text { Proposed Area 2 } \\
\text { (Existing configuration) }\end{array}$ & $-24,072 \mathrm{~m}^{3}\left[31,460 \mathrm{yd}^{3}\right]$ & $-15,454 \mathrm{~m}^{3}\left[20,200 \mathrm{yd}^{3}\right]$ \\
\hline Proposed Area 3 & $\left(+266.3 \mathrm{~m}^{3}\left[348 \mathrm{yd}^{3}\right]\right)$ & $\left(+163.5 \mathrm{~m}^{3}\left[214 \mathrm{yd}^{3}\right)\right.$ \\
(Existing configuration) & $-14,713 \mathrm{~m}^{3}\left[19,230 \mathrm{yd}^{3}\right]$ & $-7,934 \mathrm{~m}^{3}\left[10,370 \mathrm{yd}^{3}\right]$ \\
\end{tabular}

*Volume change in parentheses is for existing configuration.

Figure 28 shows the morphology change in the Charleston Harbor region at the end of the calm summer simulation for the existing condition. Figures 29 through 31 show the morphology change in the Charleston Harbor region with the $400,000 \mathrm{~m}^{3}(523,000 \mathrm{yd} 3)$ of dredged material placement at each area, at the end of the calm summer period. Similar erosion and accretion patterns were observed in the Charleston Harbor region for the existing configuration and for the three placement areas, except within the immediate borderlines of the three placement areas. These figures show similar erosion and accretion patterns as depicted during the active winter, but with less intensity. Table 4 shows that minimal net sediment gain was observed at Area 2 and minimal net erosion was observed at Areas 1 and 3 for the existing configuration. Net sediment erosion volumes occurred at the three placement Areas 1, 2, and 3 of $0.6 \%, 3.9 \%$, and $2.0 \%$, respectively, of the $400,000 \mathrm{~m}^{3}\left(523,000 \mathrm{yd}^{3}\right)$ placement material, for the calm summer period. Maximum sediment erosion was observed within Area 2.

The three potential placement areas were selected because historical data indicated that they are expected to be naturally eroding. Table 4 shows that the three areas were accreting during the active winter period. Typically during large wave events, the sediment gets transported off the beach face and deposited offshore, and this might explain the sediment gain during active conditions. Areas 1 and 3 were eroding during calm conditions as suggested by historical data. Area 2 is located in a region where the remnant main-ebb channel is infilling, and this might explain the sediment gain during calm conditions. Area 2 is located in a complicated region denoted as the "breakers," and the high wave energy in this region is expected to erode berms placed in Area 2. 
Figure 28. Morphology change at end of calm summer period for existing condition.

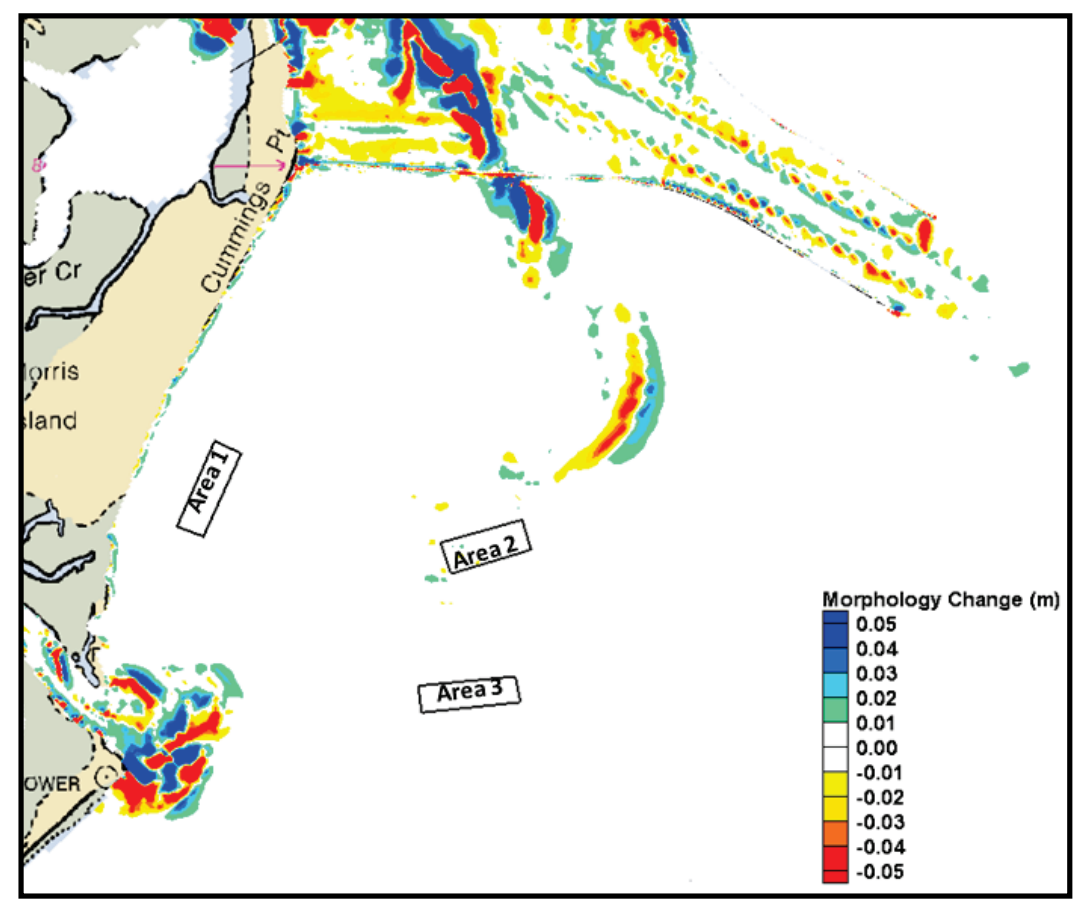

Figure 29. Morphology change at end of calm summer period for placement at Area 1.

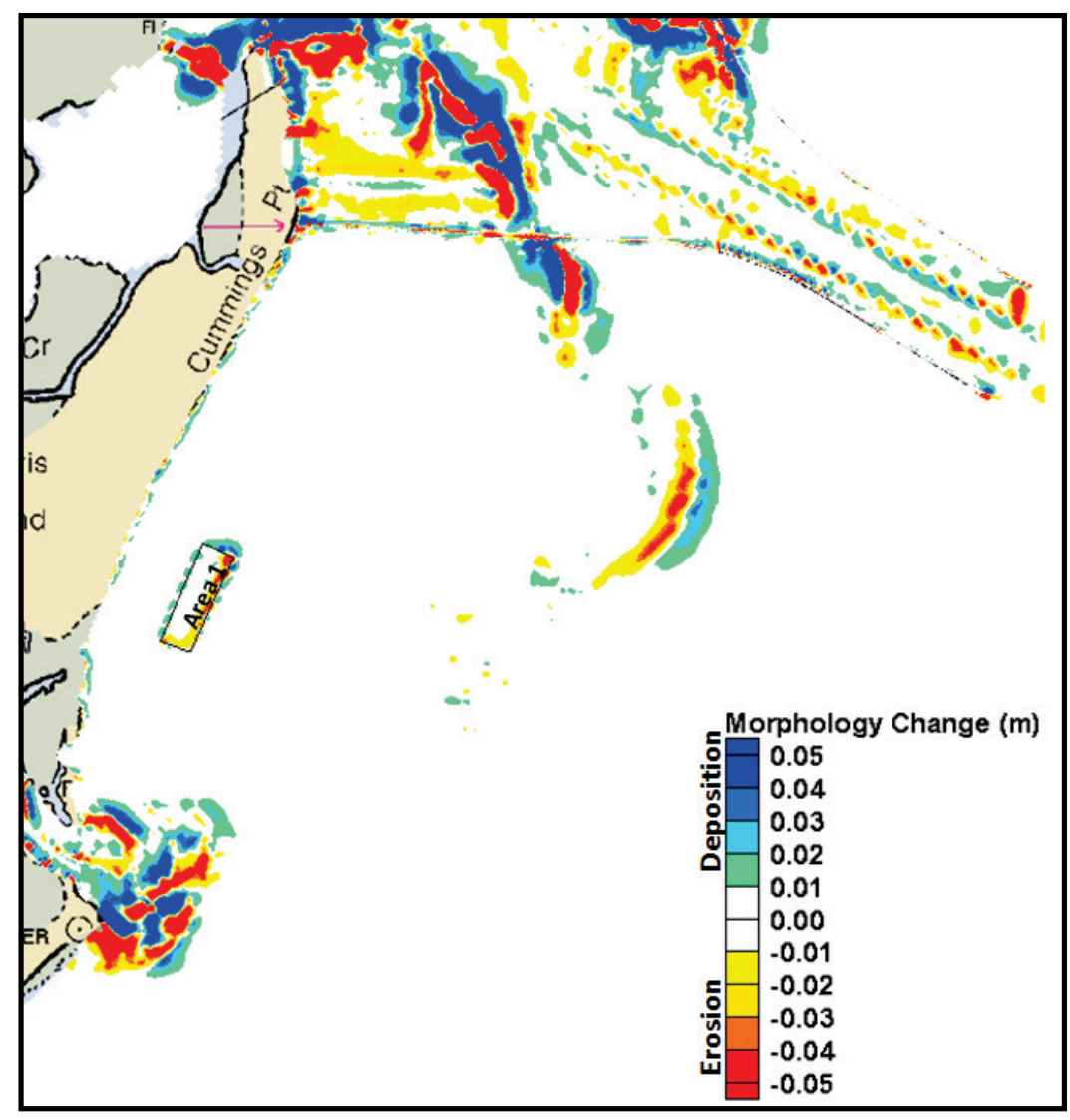


Figure 30. Morphology change at end of calm summer period for placement at Area 2.

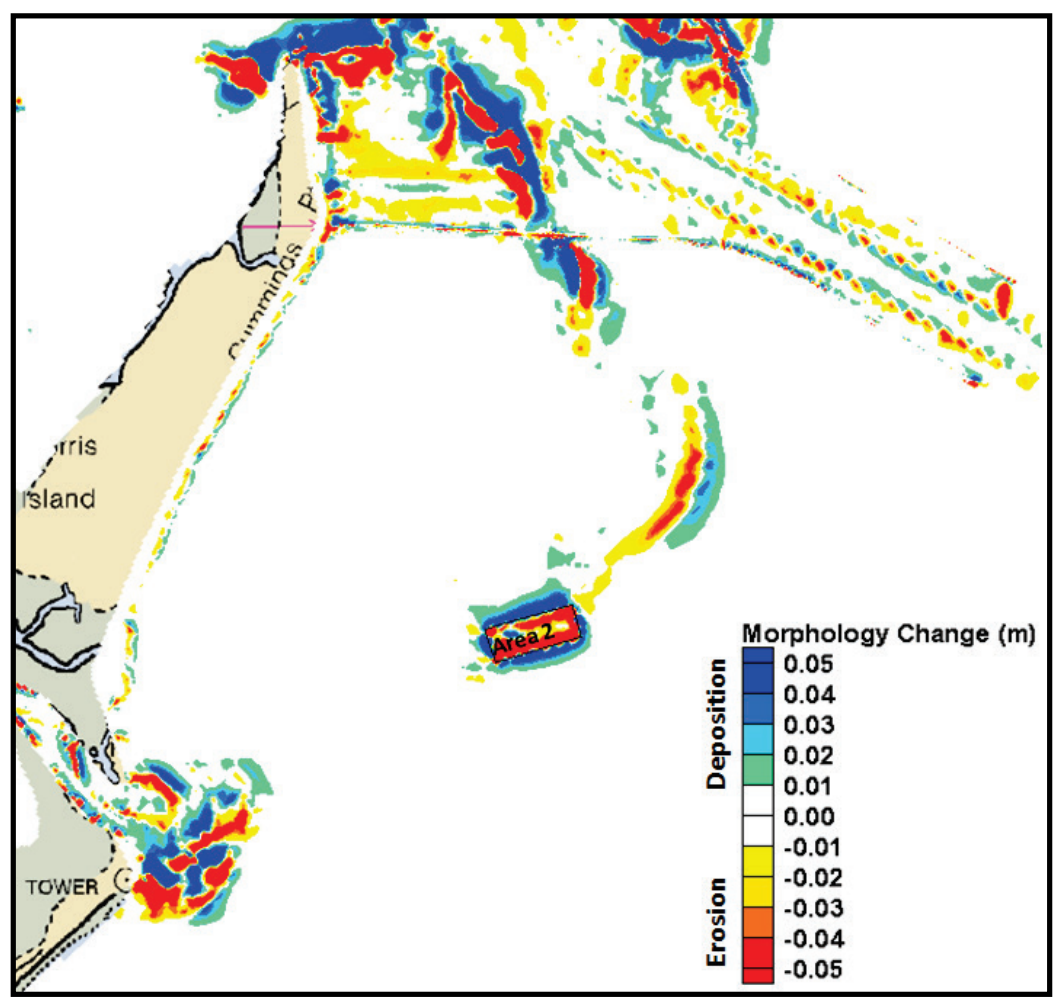

Figure 31. Morphology change at end of calm summer period for placement at Area 3.

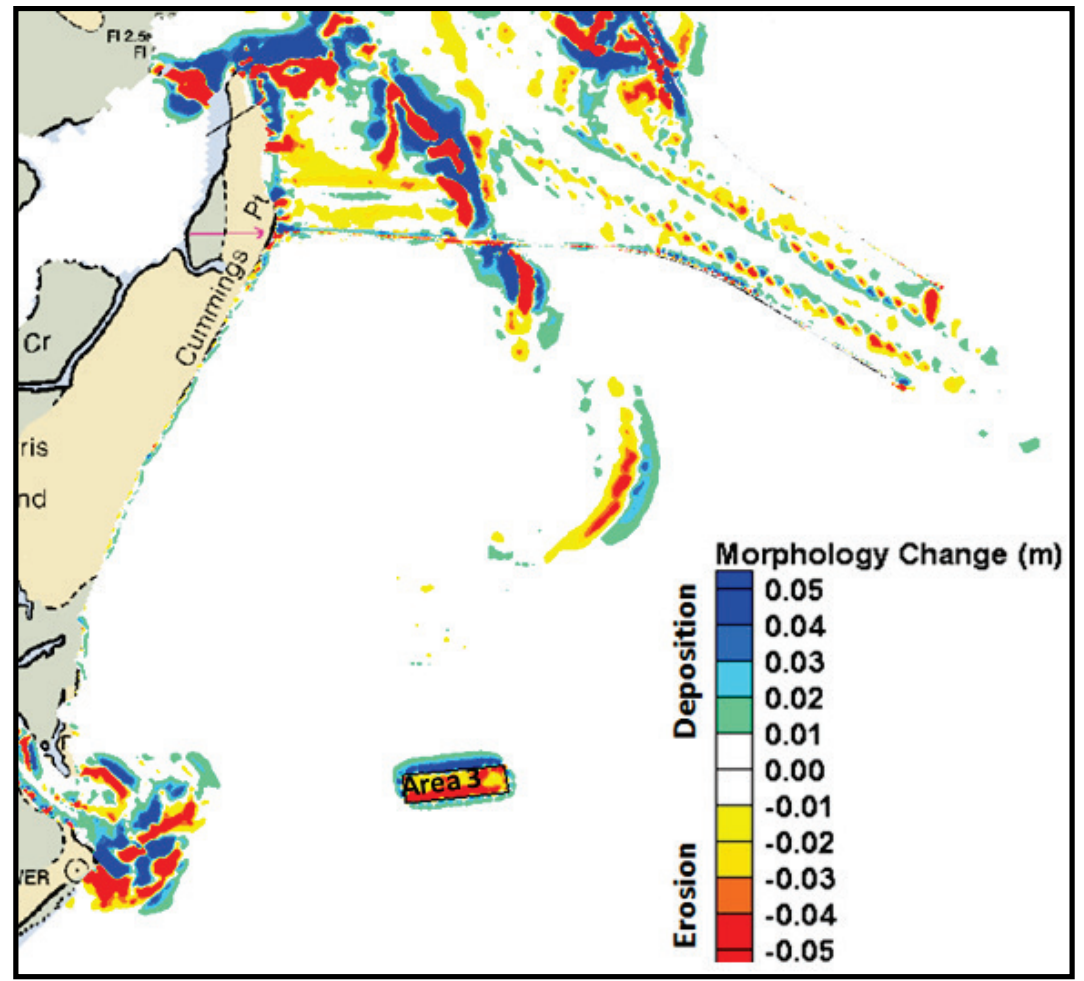


Model results were analyzed for morphology change differences between the existing condition and with placement conditions at the three proposed areas. The effect of placing dredged sediment at the three proposed areas as compared to the existing condition without the dredge material placement is shown in Figures 32 thru 34, at the end of the active winter period. Figure 32 shows that placing the dredged material at Area 1 would result in some deposition along Morris Island shorelines and with minimal deposition inside the jettied region. Figure 33 shows that sediment erosion was depicted to the northeast of Area 2 and that considerable erosion and deposition occurred inside the jettied region. Figure 34 shows that placing the dredged material at Area 3 would result in some deposition inside the jettied region. Also, some erosion and deposition occurred to the north of the placement Area 3 and within the ebb tidal delta and inside the Lighthouse Inlet. Negligible morphology change was observed along the northern portion of Folly Island during the active winter period.

Figure 32. Morphology change difference between existing and with placement at Area 1 at end of active winter period. (There is no change in the areas not shown on the figure.)

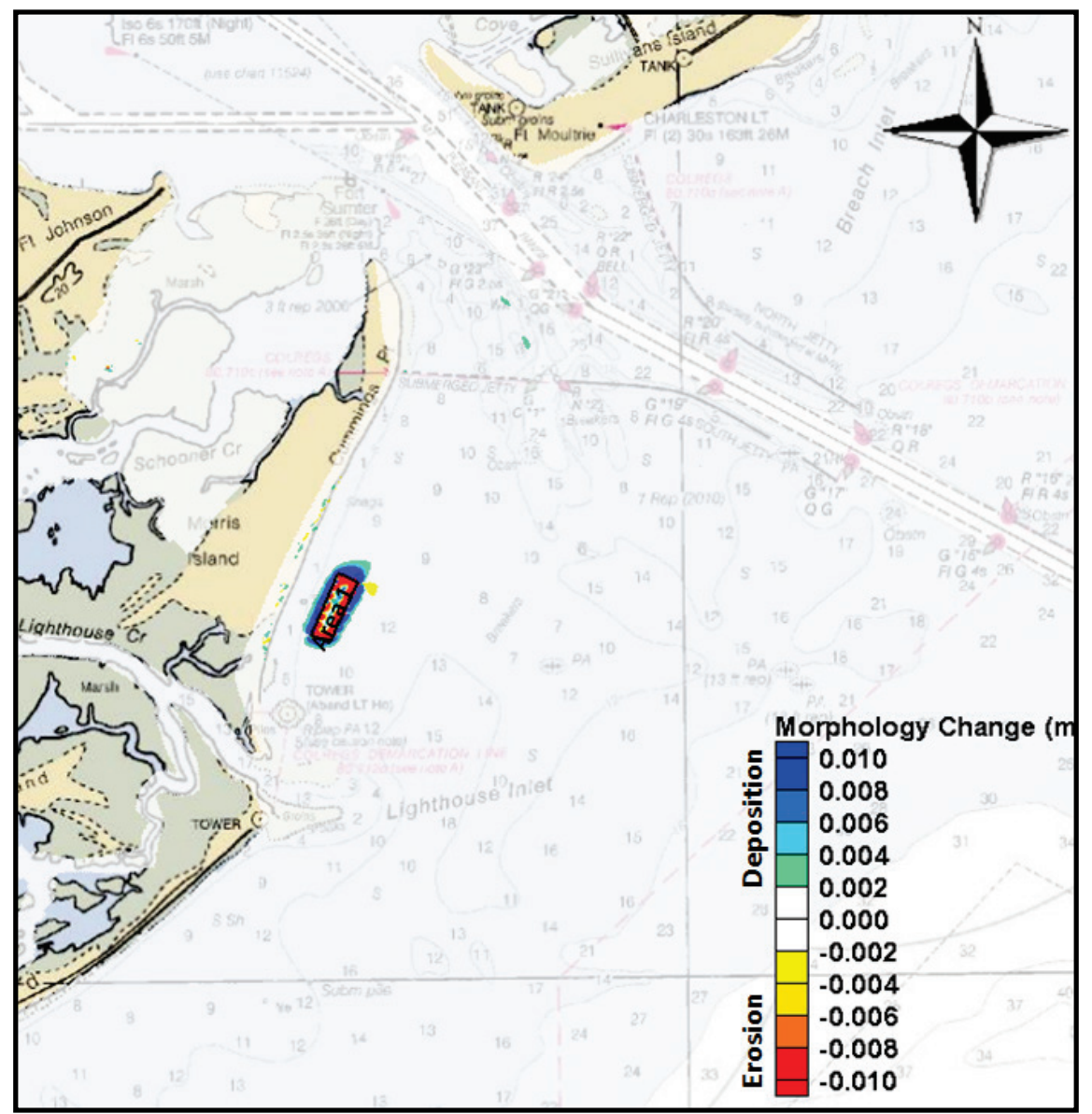


Figure 33. Morphology change difference between existing and with placement at Area 2 at end of active winter period. Since the dynamite hole region is very active, morphology change is expected to be observed during the short time of the simulation. (There is no change in the regions not shown on the figure.)

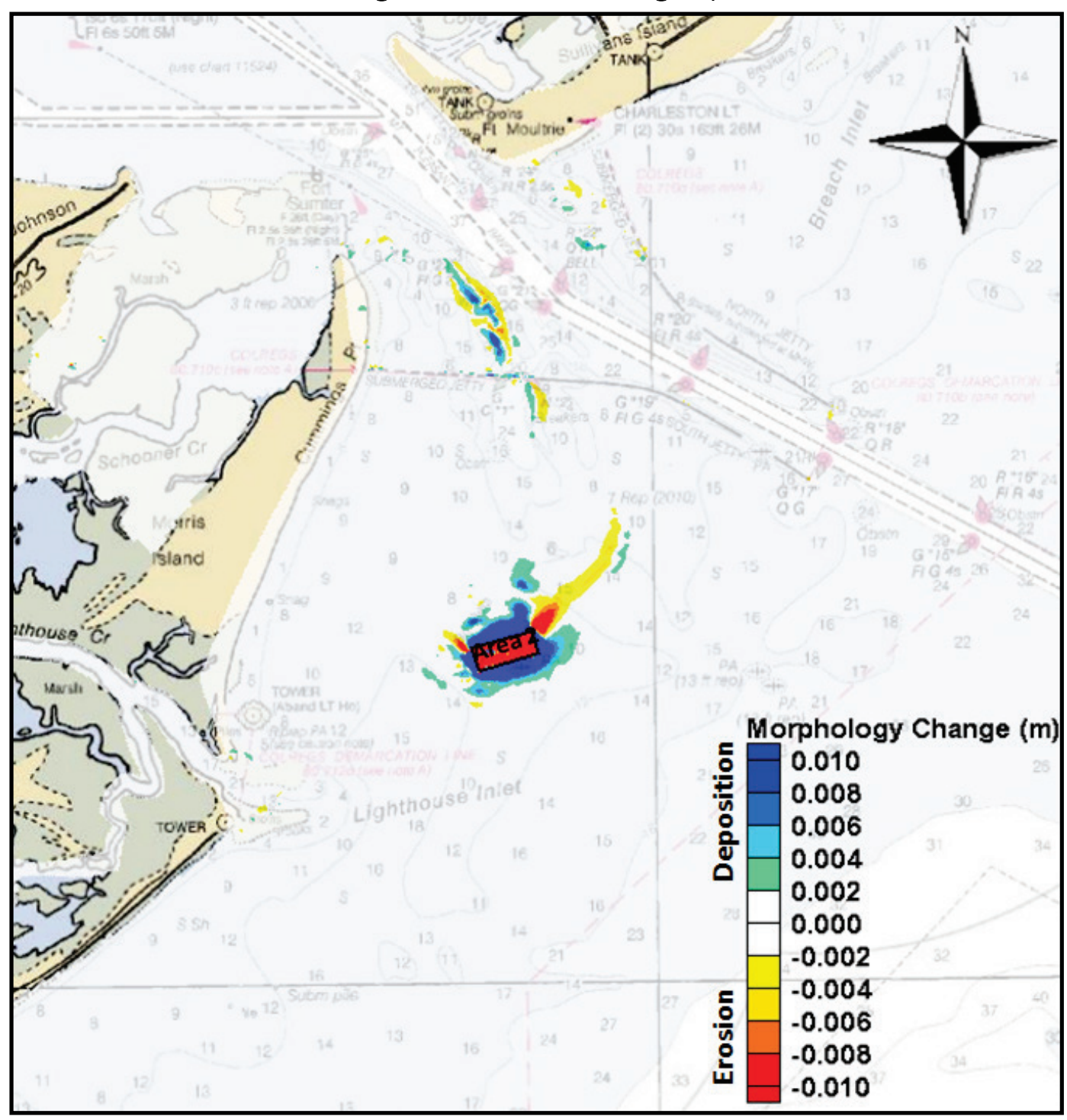


Figure 34. Morphology change difference between existing and with placement at Area 3 at end of active winter period. (There is no change in the areas not shown on the figure.)

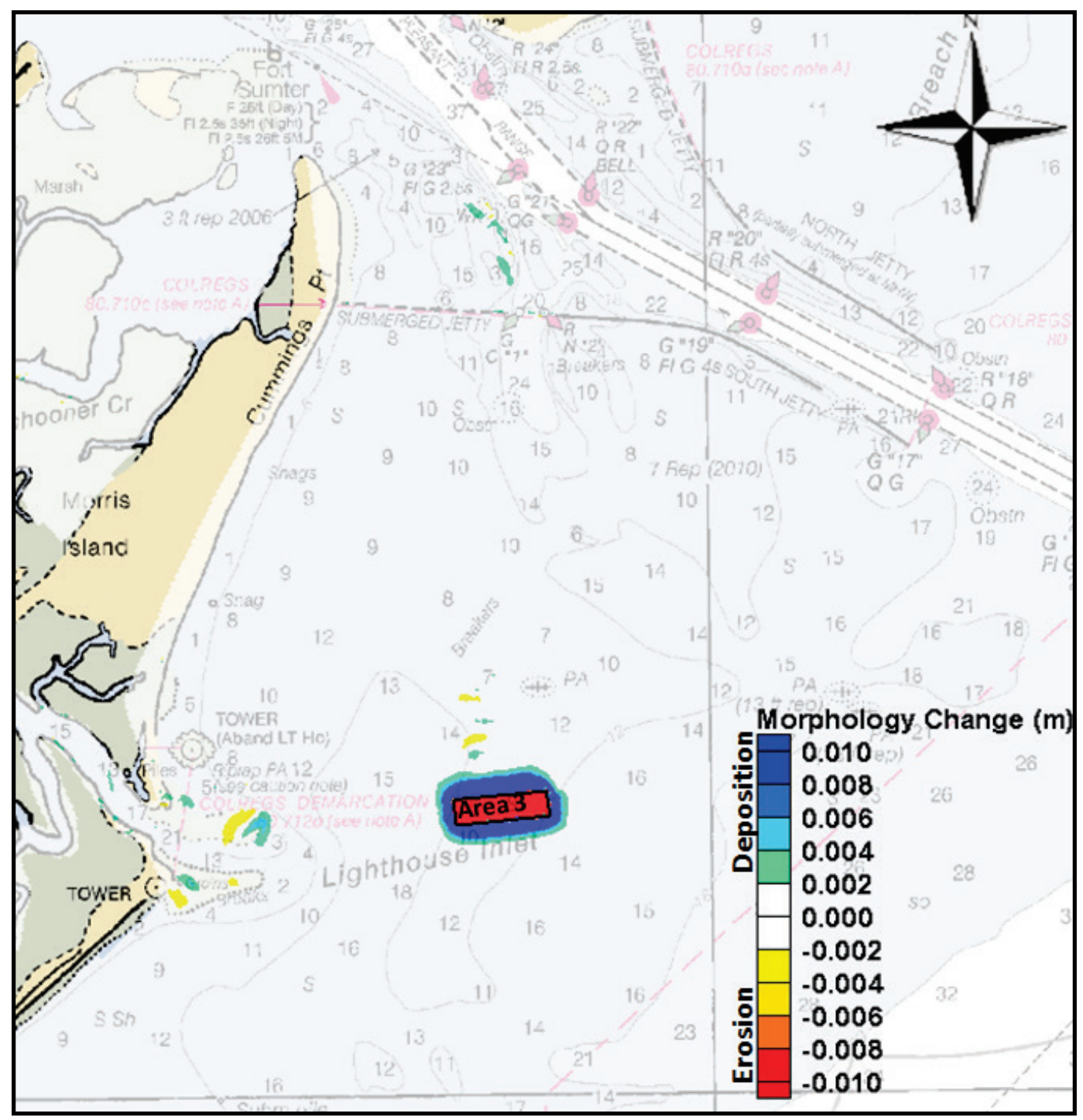

The effect of placing dredged sediment at the three proposed areas as compared to the existing configuration without the dredge material placement is shown in Figures 35 through 37, at the end of the calm summer period. The resulting erosion and deposition patterns are similar to the ones observed during the active winter period when severe weather induced more erosion and deposition. Negligible morphology change was observed along the northern portion of Folly Island (south of the tower) during the calm simulation period. 
Figure 35. Morphology change difference between existing and with placement at Area 1 at end of calm summer period. (There is no change in the regions not shown on the figure.)

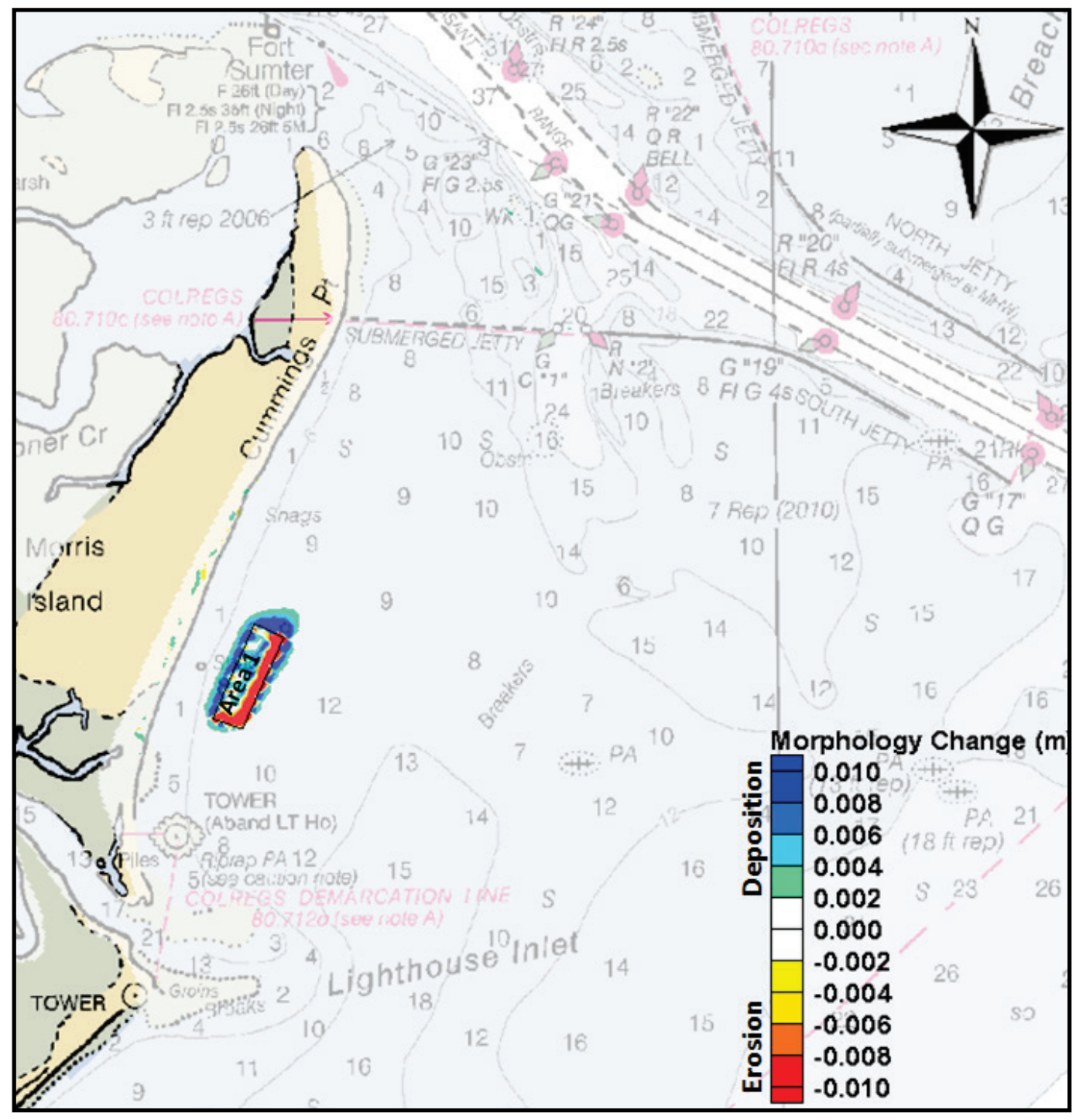


Figure 36. Morphology change difference between existing and with placement at Area 2 at end of calm summer period. (There is no change in the regions not shown on the figure.)

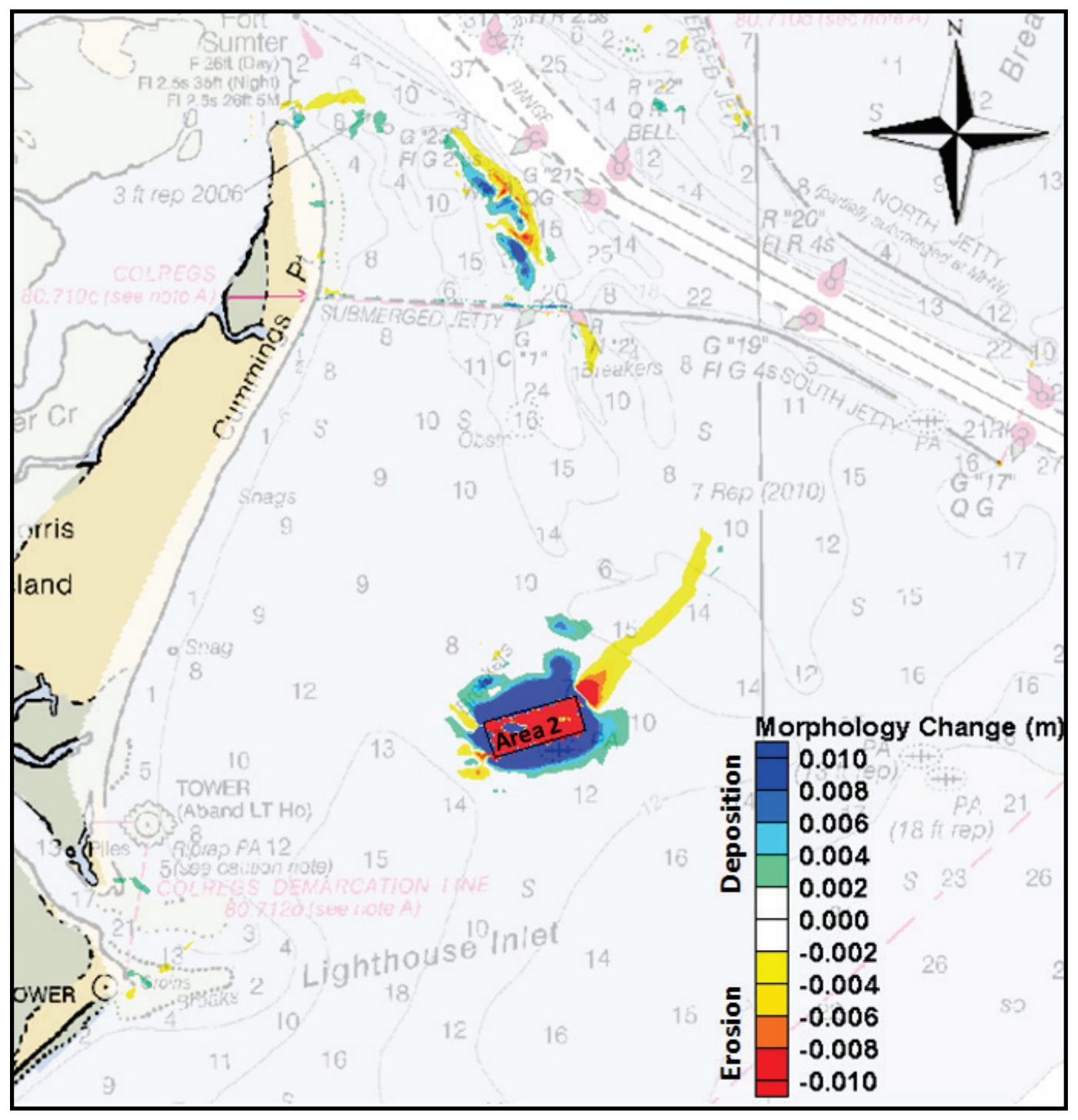


Figure 37. Morphology change difference between existing and with placement at Area 3 at end of calm summer period. (There is no change in the regions not shown on the figure.)

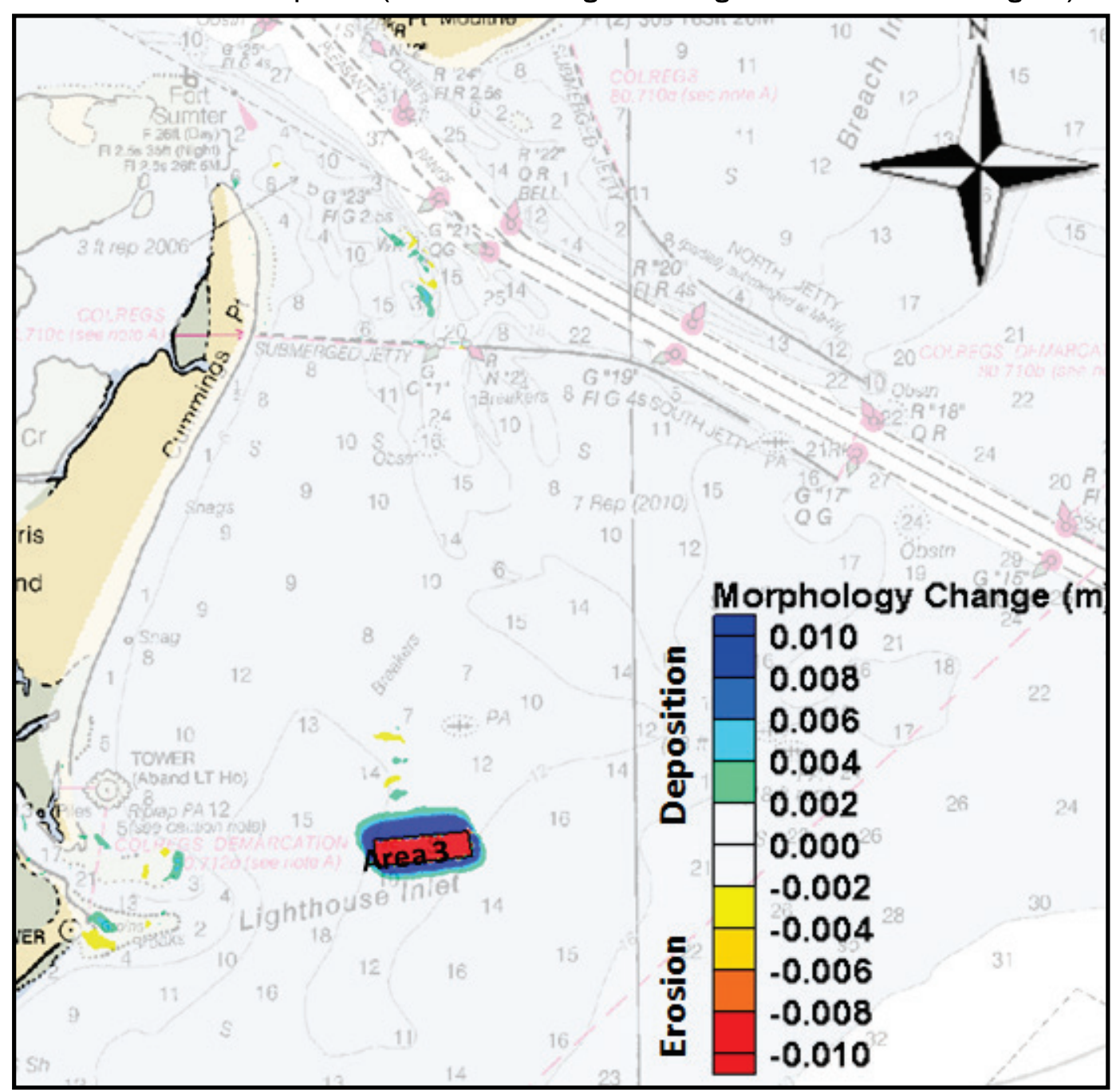

In summary, model results show that placing the material at placement Area 1 resulted in maximum deposition along the Morris Island southern shorelines and the least deposition inside the jettied region and in the vicinity of the ebb-tide delta of Lighthouse Inlet. Increased volume loss was observed at placement Area 2 with increased deposition inside the jettied region. Placing the material at Area 3 resulted in increased deposition and erosion in the vicinity of the ebb-tidal delta of Lighthouse Inlet. The active winter caused more intense erosion and deposition in the region. In addition, negligible morphology change was observed along the northern portion of Folly Island (south of the tower) during the active winter and the calm summer simulation periods. 


\section{Particle Tracking Model (PTM)}

The Particle Tracking Model (PTM) is capable of introducing and following the trajectory of discrete particles in the flow field (Demirbilek et al. 2008). PTM computes the paths of sediment particles using the Lagrangian method through a geometric domain as the particles interact with the environmental forcing. The computational environment includes the hydrodynamic flow, wave conditions, sediment property, and land boundary. Therefore, water surface elevations and tide- and wave-induced currents calculated by CMS drive the PTM computations in the same CMS domain. The SMS includes tools to generate the necessary information to define the PTM environment, such as sediment release method and sediment properties (Lin et al. 2013). The hydrodynamic simulation is separate from PTM simulations. Therefore, multiple dredging and sediment placement scenarios can be simulated using one hydrodynamic simulation. This reduces CPU time required to assess dredging-related events and permits simulation of multiple scenarios.

Placing the material at Area 1 resulted in maximum deposition along the Morris Island southern shoreline. Also, it resulted in the least deposition inside the jetties (close to the navigation channel) and in the vicinity of the ebb-tidal delta of Lighthouse Inlet. Therefore, Area 1 was considered the optimal placement location, and accordingly, PTM was applied to assess the transport patterns and pathways of fine sediment from Area 1 only.

New work dredged material from a deepening project within the Charleston Entrance Channel, based on limited sampling, was identified to be composed of approximately $80 \%$ sand with a small percentage of gravel, silt, and clay. Sand is expected to settle close to the placement area while fine material would be transported farther inland and offshore away from the placement area. Therefore, the pathways of fine material are evaluated in this PTM study. Silts are approximately $10 \%$ of the dredge material (Table 2). Silt with $\mathrm{D}_{50}$ of $0.02 \mathrm{~mm}$ (0.0008 in.) was considered to be representative of the fine dredged material and was used for the PTM source particle characteristics.

Native bed sediment was defined by $\mathrm{D}_{35}, \mathrm{D}_{50}$, and $\mathrm{D}_{90}$ for each cell, where $\mathrm{D}_{35}$ is the 35-percentile grain size and $\mathrm{D}_{90}$ is the 90-percentile grain size. Grain size distribution was investigated by examining an available borehole database. The values of $\mathrm{D}_{35}, \mathrm{D}_{50}$, and $\mathrm{D}_{90}$ used in the simulation 
were estimated at $0.15 \mathrm{~mm}$ (0.006 in.), $0.18 \mathrm{~mm}$ (0.007 in.), and $0.3 \mathrm{~mm}$ (o.012), respectively (Kashlan 2013).

Details of the dredging operations such as specific location, equipment, and the length of the operation were not specified in this study because the main objective is to address the feasibility of the nearshore placement in the study region. Particles can be released from different source options (points, lines, or areas). The source specified was a point mass rate source that produces particles at a specific rate over time. Silt material was released at a rate level to simulate fine sediment movement during and after the release of the dredged material by a point source at the placement area. The release point was selected within placement Area 1. The PTM three-dimensional (3-D) mode is required to accurately predict the movement of fine sediment (MacDonald et al. 2006). A 100-second (sec) time-step was used in the 3-D model option for modeling silt particles.

The Charleston Harbor Entrance Channel dredging window occurs during the winter (December-March). Therefore, the PTM simulations were conducted during a 7-day period (5-11 December 2012) to evaluate sediment pathways during the release of the dredged material.

A hypothetical placement operation of particle release once a day for the 7-day period was adopted. The duration of each release was assumed to last for 10 minutes, and sediment particles were introduced into the system at a mass rate of $15 \mathrm{kilograms} / \mathrm{second}(\mathrm{kg} / \mathrm{sec})$. Details of the real placement operation were not available during the preparation of this report, but it is expected that material will be disposed more frequently and at a higher mass rate.

Figure 38 shows the pathway of fine material from the source at the end of the 7-day simulation period. Red particles indicate deposited sediments, and blue particles indicate sediment in suspension. Fine sediments were transported into the inland channels and inside the harbor and the jettied region. A large portion of the fine sediments moved in suspension along Morris Island shorelines and around the Island's northeastern tip. Sediments were also observed in front of Folly Island shoreline. Some sediment moved offshore beyond the seaward tips of the Entrance Channel jetties. PTM results indicate that placing the dredged material at Area 1 will result in some deposition of silt in front of Folly Island and within the inner channels, in good agreement with the CMS results. A 
considerable portion of the fines is in suspension and is transported offshore, back into the navigation channel, and inside the harbor region. The PTM simulation also shows suspended sediments were observed in front of the northern portion of Folly Island shoreline.

Figure 38. Silt particle distribution at end of 7-day simulation at Area 1. Red particles indicate deposited sediments. Blue particles indicate sediment in suspension.

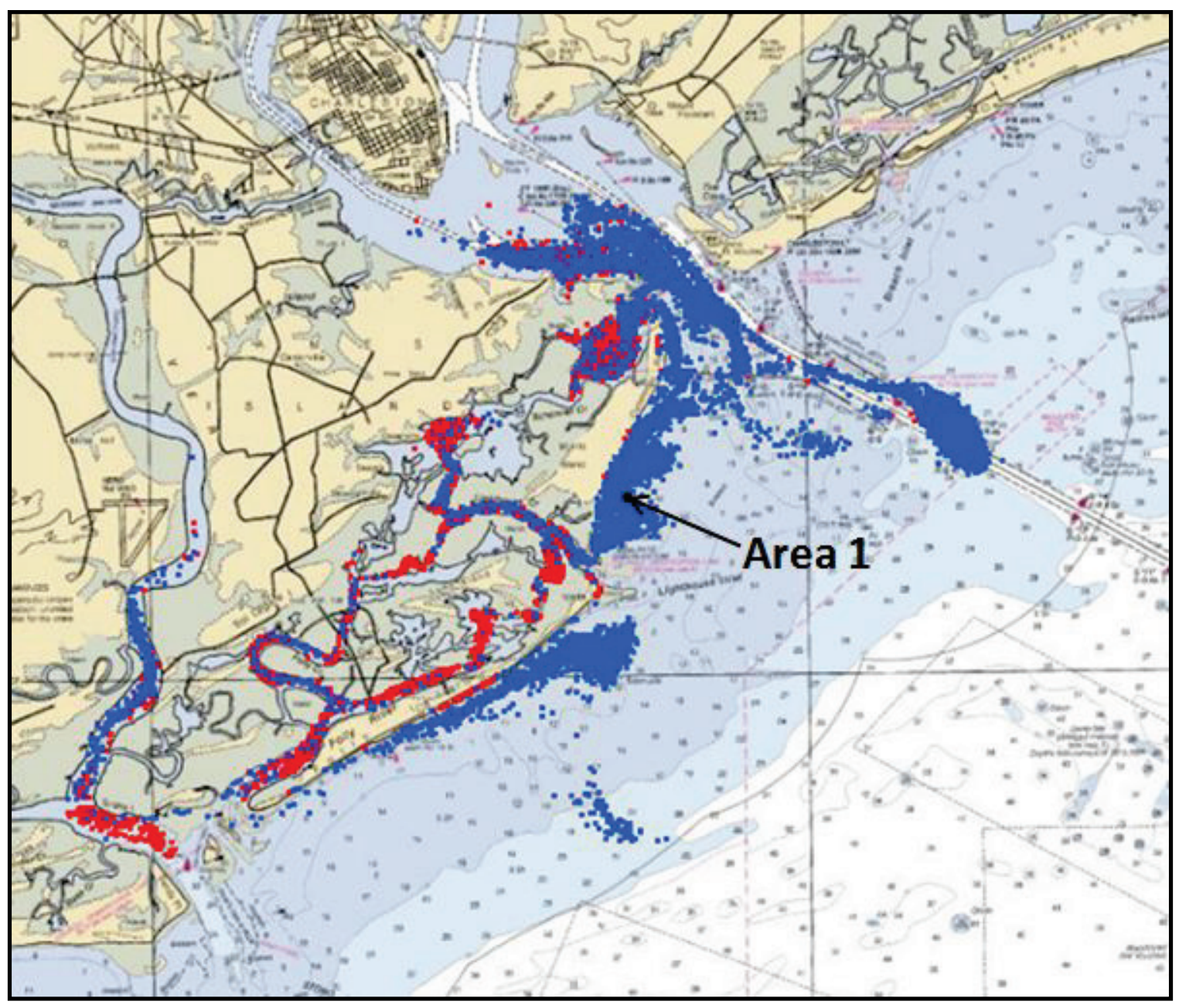




\section{Conclusions and Recommendations}

\section{Conclusions}

Dredged material to be removed from Charleston Harbor Entrance Channel for a proposed deepening project is estimated based on limited sampling to be composed of approximately $80 \%$ sand and thus does not meet guidelines for direct beach placement. Therefore, instead of transporting the material to the offshore ODMDS and consequently removing the sand from the littoral system, nearshore placement of the sediment may be considered a beneficial use of the dredged material. The USACE CMS-Flow and CMS-Wave numerical models were utilized to evaluate sediment transport benefits associated with nearshore placement of $400,000 \mathrm{~m}^{3}(523,000 \mathrm{yd} 3)$ of the Charleston Harbor Entrance Channel new work dredged material in one of three proposed potential areas south of the Charleston Harbor south jetty. CMS-Flow was forced by coastal water level, wind, and river flow data, CMS-Wave was forced with measured wave data collected by the EPA at the Offshore ADCP. The inline version of CMS-Flow, which includes CMS-Flow and CMS-Wave in one code, was used in the present study because of its capability to implement the tidal constituent forcing at the ocean boundary and because of the telescoping grid of CMS-Flow.

Three proposed locations for the nearshore placement were selected based on review of relevant historical data, distance from the navigation channel, and berm stability criteria. The selection excludes cultural, economic, and environmental considerations. A rectangular region with a $2.0 \mathrm{~m}(6.6 \mathrm{ft})$ layer above the existing seabed was specified inside the three proposed placement areas.

Sediment transport and morphology change at the proposed dredged material placement areas were investigated for selected active winter and calm summer periods. The CMS models were used to estimate sediment transport patterns before and after dredged material had been placed in the littoral zone within the three proposed placement areas south of the jetties. Model simulations included the existing configuration and the three potential nearshore dredged material placement areas with afterplacement bathymetry. 
Morphology change in the Charleston Harbor region was estimated at the end of the active winter and calm summer simulation periods for the existing condition and the three potential placement areas. Model results show similar erosion and accretion patterns in the Charleston Harbor region for the existing configuration and for the three potential placement areas, except within the immediate borderlines of the three areas. Net sediment erosion occurred at the three areas with erosion of $1.4 \%, 6.0 \%$, and $3.7 \%$ of the $400,000 \mathrm{~m}^{3}$ (523,000 yd 3 ) placement material in Areas 1 , 2 , and 3 , respectively, during the active winter period. Net sediment erosion also occurred at the three areas during the calm summer period with erosion of $0.6 \%, 3.9 \%$, and $2.0 \%$ of the $400,000 \mathrm{~m}^{3}\left(523,000 \mathrm{yd}^{3}\right)$ placement material in Areas 1, 2, and 3 respectively. The resulting erosion and deposition patterns were similar for the active winter and calm summer simulations. However, severe weather conditions induced more erosion and deposition.

Placing the material at placement Area 1 resulted in maximum deposition along the Morris Island southern shorelines and the least deposition inside the jettied region and in the vicinity of the ebb-tide delta of Lighthouse Inlet. Sediment placement in Area 2 resulted in erosion to the northeast of Area 2, and considerable erosion and deposition both occurred inside the jettied region. Placing the dredged material at Area 3 resulted in some deposition inside the jettied region. Also, some erosion and deposition occurred to the north of the placement Area 3 and within the ebb-tidal delta and inside the Lighthouse Inlet. Negligible morphology change was observed along the northern portion of Folly Island.

The least sediment erosion occurred within Area 1, but placing the dredged material at Area 1 resulted in maximum deposition along the Morris Island southern shoreline and the least deposition inside the jettied region and in the vicinity of the ebb-tidal delta of Lighthouse Inlet. Therefore, Area 1 is considered the optimal location to place the Entrance Channel dredged material.

The PTM model was applied to assess the transport patterns and pathways of fine sediment from Area 1 only. The dredged material obtained from the entrance channel was composed of a small percentage of gravel, silt, and clay. Sand is expected to settle close to the placement area while fine material would be transported farther inland and offshore away from the placement area. Fine sediments were transported into the inland channels and inside the harbor and the jettied region. A large portion of the fine 
sediments moved in suspension along Morris Island shorelines and around the Island's northeastern tip. Fine sediments were also observed in front of Folly Island shorelines. Some fine sediment moved offshore beyond the seaward tips of the Entrance Channel jetties.

PTM results indicate that placing the dredged material at Area 1 will result in some deposition of silt in front of Folly Island and within the inner channels. A considerable portion of the fines are in suspension and are transported offshore, back into the navigation channel, and inside the harbor region. Also, suspended sediments were observed in front of the northern portion of Folly Island shoreline. It is expected that the real placement operation will introduce more sediments into the system and at a higher frequency than the hypothetical placement operation adopted in this study. Therefore, PTM should be conducted for more realistic dredging sediment release operations and for a longer simulation period to address sediment movement in the study region.

\section{Recommendations}

The main objective of this study is to address the feasibility of nearshore placement of dredged material in the region south of the Charleston Harbor Entrance Channel south jetty. This is a pilot study, and it is recommended that dredged material should be placed at Area 1 of the three potential placement areas identified. Other placement regions may also warrant study. Preliminary dimensions of the three potential placement areas were investigated in this study. The actual design of the placement area should be evaluated in more detail in a future study that considers operational constraints. In addition, cultural, economic, and environmental concerns need to be addressed during the selection of the optimal placement area.

As more detailed sediment characteristics of the new work dredge material are available, this analysis will need to be re-evaluated. It is recommended that longer simulations by CMS-Flow and CMS-Wave models be conducted to provide better understanding of long-term morphology change along Morris Island and the northern portion of Folly Island. Details of the dredging operations such as specific location, equipment, and length of the operations were not available during the preparation of this study. It is also recommended that PTM modeling for more realistic dredging sediment release operations, and for the final placement area location and dimensions, be conducted for longer model simulation periods. 


\section{References}

ANAMAR. 2013. Charleston Harbor navigation improvement project (Post 45): Dredging; Marine Protection, Research, and Sanctuaries Act of 1972, Section 103, Sediment testing and analysis, Charleston, South Carolina. Gainesville, FL: ANAMAR Environmental Consulting, Inc.

Beck, T. B., J. D. Rosati, and J. Rosati. 2012. An Update on nearshore berms in the Corps of Engineers: Recent projects and future needs. ERDC/CHL CHETN-XIV-19. Vicksburg, MS: U.S. Army Engineer Research and Development Center. http://acwc.sdp.sirsi.net/client/en_US/search/asset/1011303

Buttolph, A. M., C. W. Reed, N. C. Kraus, N. Ono, M. Larson, B. Camenen, H. Hanson, T. Wamsley, and A. Zundel. 2006. Two-dimensional depth-averaged circulation model CMS-M2D: version 3.o; report 2, sediment transport and morphology change. ERDC/CHL TR-06-9. Vicksburg, MS: U.S. Army Engineer Research and Development Center. http://acwc.sdp.sirsi.net/client/search/asset/1000764

Demirbilek, Z., K. J. Connell, N. J. MacDonald, and A. K. Zundel. 2008. Particle Tracking Model in the SMS1O: IV. Link to Coastal Modeling System. ERDC/CHL CHETN-IV-71. Vicksburg, MS: U.S. Army Engineer Research and Development Center. http://acwc.sdp.sirsi.net/client/search/asset/1000430

Demirbilek, Z., and J. D. Rosati. 2011. Verification and validation of the Coastal Modeling System: Report 1; Summary report. ERDC/CHL TR-11-10. Vicksburg, MS: U.S. Army Engineer Research and Development Center. http://acwc.sdp.sirsi.net/client/search/asset/1005704

EPA. 2014. Charleston Harbor ODMDS current and wave measurements: Regional sediment management current and wave measurements. EPA-904-14. Atlanta, GA: U.S. Environmental Protection Agency, Region 4.

Fitzgerald, D. M., C. Fico, and M. O. Hayes. 1979. Effects of the Charleston Harbor, SC, jetty construction on local accretion and erosion. In Proceedings, Coastal Structures '79, Seventh Symposium of the Waterway, Port, Coastal, and Ocean Division of the American Society of Civil Engineers, 641-664. New York, NY.

Gailani, J. Z., T. C. Lackey, and S. J. Smith. 2007. Application of the Particle Tracking Model to predict far-field fate of sediment suspended by nearshore dredging and placement, Brunswick Ga. In Proceedings, XVIII World Dredging Conference. Lake Buena Vista, FL: Western Dredging Association, 39-6o.

Hallermeier, R. J. 1981. A profile zonation for seasonal sand beaches from wave climate. Coastal Engineering 4(3):253-277.

Hands, E. B., and M. C. Allison. 1991. Mound migration in deeper water, and methods of categorizing active and stable depths. In Proceedings, Coastal Sediments '91. New York, NY: American Society of Civil Engineers, 1985-1999. 
Hansen, M., and S. C. Knowles. 1988. Ebb-tidal delta response to jetty construction at three South Carolina inlets. Hydrodynamics and sediment dynamics of tidal inlets; Lecture notes on coastal estuarine studies. Edited by D. G. Aubrey and L. Weishar. (29)364-381. Washington, DC: American Geophysical Union. doi 10.1029/LNo29po364.

Kashlan, Layla R. 2013. Numerical modeling study, Charleston Harbor coastal area, SC. Charleston, SC: U.S. Army Engineer District, Charleston.

Lillycrop, L. S., J. D. Rosati, J. M. Wozencraft, and R. Dopsovic. 2011. Advancement of technologies for practicing Regional Sediment Management. In Proceedings, Coastal Sediments Conference 2011, 2,016-2,074. Miami, FL.

Lin, L., Z. Demirbilek, H. Mase, J. Zheng, and F. A. Yamada. 2008. Nearshore spectral wave processes model for coastal inlets and navigation projects. ERDC/CHL TR-08-13. Vicksburg, MS: U.S. Army Engineer Research and Development Center. http://acwc.sdp.sirsi.net/client/search/asset/1000803

Lin, L., Z. Demirbilek, R. Thomas, and J. Rosati III. 2011. Verification and validation of the Coastal Modeling System: Report 2; CMS-Wave. ERDC/CHL TR-11-10. Vicksburg, MS: U.S. Army Engineer Research and Development Center. http://acwc.sdp.sirsi.net/client/search/asset/1005705

Lin, L., H. Li, M. Brown, F. Wu, and L. Andes. 2013. Pilot study evaluating nearshore sediment placement sites, Noyo Harbor, CA. ERDC/CHL TR-13-2. Vicksburg, MS: U.S. Army Engineer Research and Development Center. http://acwc.sdp.sirsi.net/client/en_US/search/asset/1024604

MacDonald, N. J., M. H. Davies, A. K. Zundel, J. D. Howlett, Z. Demirbilek, J. Z. Gailani, T. C. Lackey, and J. Smith. 2006. PTM: Particle Tracking Model; Report 1: Model theory, implementation, and example applications. ERDC/CHL TR-6-20. Vicksburg, MS: U.S. Army Engineer Research and Development Center. http://acwc.sdp.sirsi.net/client/search/asset/1000777

McArthur, C. 2012. Quality assurance project plan: Charleston Harbor ODMDS current and wave measurements; and inshore regional sediment management (RSM) current and wave measurements. Atlanta, GA: U.S. Environmental Protection Agency, Region 4.

Mukai, A. Y., J. J. Westerink, R. A. Luettich, and D. J. Mark. 2002. Eastcoast 2001: A tidal constituent database for the western North Atlantic, Gulf of Mexico, and Caribbean Sea. ERDC/CHL TR-02-24. Vicksburg, MS: U.S. Army Engineer Research and Development Center.http://hdl.handle.net/11681/7521

Sanchez, A., and W. Wu. 2011. A non-equilibrium sediment transport model for coastal inlets and navigation channels. Journal of Coastal Research Special Issue 59:3948. West Palm Beach, FL: Coastal Education and Research Foundation.

Sanchez, A., W. Wu, T. M. Beck, H. Li, J. D. Rosati, Z. Demirbilek, and M. Brown. 2011a. Verification and validation of the Coastal Modeling System: Report 4; Sediment transport and morphology change. ERDC/CHL TR-11-10. Vicksburg, MS: U.S. Army Engineer Research and Development Center. http://acwc.sdp.sirsi.net/client/search/asset/1005707 
Sanchez, A., W. Wu, T. M. Beck, H. Li, and J. Rosati III. 2011b. Verification and validation of the Coastal Modeling System: Report 3; CMS-Flow, Hydrodynamics. ERDC/CHL TR-11-10. Vicksburg, MS: U.S. Army Engineer Research and Development Center. http://acwc.sdp.sirsi.net/client/search/asset/1005706

Sanchez, A., L. Lin, Z. Demirbilek, T. Beck, M. Brown, H. Li, J. Rosati, W. Wu, C. Reed, and A. Zundel. 2014a. Coastal Modeling System: User manual. Vicksburg, MS: U.S. Army Engineer Research and Development Center. http://cirpwiki.info/wiki/CMS

Sanchez, A., W. Wu, H. Li, M. Brown, C. Reed, J. Rosati, and Z. Demirbilek. 2014b. Coastal Modeling System: Mathematical formulations and numerical methods. ERDC/CHL TR-14-2. Vicksburg, MS: U.S. Army Engineer Research and Development Center. http://hdl.handle.net/11681/7361

Sargent, F. E. 1988. Case histories of Corps breakwater and jetty structures: Report 2; South Atlantic Division. REMR-CO-3. Vicksburg, MS: U.S. Army Waterways Experiment Station.

Smith, E. R., and J. Z. Gailani. 2005. Nearshore placed mound physical model experiment. ERDC TN-DOER-D3. Vicksburg, MS: U.S. Army Engineer Research and Development Center.http://acwc.sdp.sirsi.net/client/search/asset/1003935

Stapor, F. W., and J. P. May, 1987. Sediment transport and ebb-tidal delta development at Charleston Harbor Entrance. In Proceedings, Coastal Sediments '87, American Society of Civil Engineers, 1,640-1,655. New York, NY.

U.S. Army Corps of Engineers. (USACE). 2008. Coastal Engineering Manual: Part V, Coastal project planning and design. Chapter 4, Beach fill design. EM 1110-21100. Washington, DC: Headquarters, U.S. Army Corps of Engineers.

2009. Dredged material management plan: Preliminary assessment; Charleston Harbor, South Carolina. Charleston, SC: U.S. Army Engineer District, Charleston.

2010. Section 905(b) (WRDA 86) analysis: Charleston Harbor navigation improvement project: Charleston, South Carolina. Charleston, SC: U.S. Army Engineer District, Charleston.

2012. Regional Sediment Management at East Rockaway Inlet, $N Y$, utilizing the USACE Coastal Modeling System. ERDC/CHL CHETN-XIV-22. Prepared by U.S. Army Engineer District, New York; numerical modeling supported by Offshore and Coastal Technologies, Inc., Chadds Ford, PA. Vicksburg, MS: U.S. Army Engineer Research and Development Center. http://acwc.sdp.sirsi.net/client/search/asset/1024680

2015. Charleston Harbor post 45 final feasibility; Final integrated feasibility report and environmental impact statement. Charleston, SC: U.S. Army Engineer District, Charleston. 


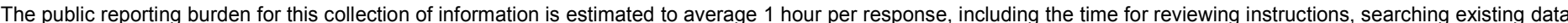

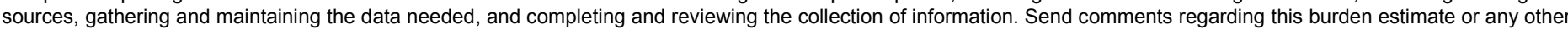

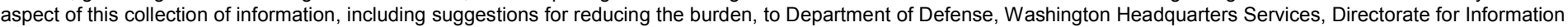

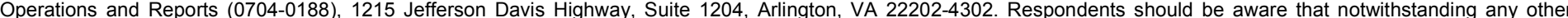
provision of law, no person shall be subject to any penalty for failing to comply with a collection of information if it does not display a currently valid OMB control number. PLEASE DO NOT RETURN YOUR FORM TO THE ABOVE ADDRESS.

\begin{tabular}{l|l|l}
\hline $\begin{array}{l}\text { 1. REPORT DATE } \\
\text { May } 2017\end{array}$ & $\begin{array}{l}\text { 2. REPORT TYPE } \\
\text { Final Report }\end{array}$ & 3. DATES COVERED (From - To)
\end{tabular}

\section{TITLE AND SUBTITLE}

5a. CONTRACT NUMBER

Charleston Harbor, SC, Regional Sediment Management Study; Beneficial Use of Dredged Material through Nearshore Placement

\section{5b. GRANT NUMBER}

5c. PROGRAM ELEMENT NUMBER

\section{AUTHOR(S)}

Layla R. Kashlan, Sara A. Brown, and Linda S. Lillycrop

5d. PROJECT NUMBER 454632

5e. TASK NUMBER

5f. WORK UNIT NUMBER

8. PERFORMING ORGANIZATION REPORT NUMBER

ERDC/CHL TR-17-7

10. SPONSOR/MONITOR'S ACRONYM(S) HQUSACE

11. SPONSOR/MONITOR'S REPORT NUMBER(S)

\section{DISTRIBUTION/AVAILABILITY STATEMENT}

Approved for public release; distribution is unlimited.

\section{SUPPLEMENTARY NOTES}

\section{ABSTRACT}

The 2015 Charleston Harbor, SC, final feasibility study (USACE 2015) presents results of analyses of proposed modifications to the existing navigation system. The improvements would deepen the Entrance Channel from $-47 \mathrm{feet}(\mathrm{ft})$ mean lower low water (mllw) to -54 $\mathrm{ft}$ mllw. The dredged material is estimated to be $80 \%$ sand and does not meet U.S. Army Corps of Engineers guidelines for beach placement. Instead of disposing in the Ocean Dredged Material Disposal Site, nearshore placement is considered as a beneficial use. The U.S. Army Engineer Research and Development Center CMS-Flow and CMS-Wave numerical models were utilized to estimate benefits from nearshore placement of 400,000 cubic meters $(523,000$ cubic yards) of new work in three areas south of the Harbor south jetty. The least sediment erosion occurred where the material was placed in Area 1, the location nearest the shoreface. This resulted in maximum deposition along the Morris Island southern shoreline and least deposition inside the Entrance Channel and in the ebb-tide delta of Lighthouse Inlet. As more details of the new work dredge material become available, this analysis will be re-evaluated with longer simulations to better understand morphology changes along Morris Island and the northern portion of Folly Island.

\section{SUBJECT TERMS}

Charleston Harbor (S.C.), Dredging, Dredging spoil, Sedimentation and deposition, Sediment control, Sediment Transport—Computer simulation

16. SECURITY CLASSIFICATION OF:

\begin{tabular}{|l|c|l|l|r|} 
a. REPORT & b. ABSTRACT & c. THIS PAGE & ABSTRACT \\
Unclassified & Unclassified & Unclassified & SAR
\end{tabular}

18. NUMBER 1 19a. NAME OF RESPONSIBLE PERSON OF PAGES Layla R. Kashlan

57 19b. TELEPHONE NUMBER (Include area code) $910-251-4181$ 
7. PERFORMING ORGANIZATION NAME(S) AND ADDRESS(ES) (concluded)

U.S. Army Engineer District, Wilmington

P.O. Box 1890

Wilmington, NC 28402-1890

U.S. Army Engineer District, Charleston

69A Hagood Avenue

Charleston, SC 29403-0919

U.S. Army Engineer Research and Development Center

Coastal and Hydraulics Laboratory

3909 Halls Ferry Road

Vicksburg, MS 39180-6199 